\title{
Exchange rate volatility response to macroeconomic news during the global financial crisis 出
}

\author{
Walid Ben Omrane ${ }^{\mathrm{a}, 1}$, Tanseli Savaşer ${ }^{\mathrm{b}, *}$ \\ a Goodman School of Business, Brock University, Canada \\ ${ }^{\mathrm{b}}$ Faculty of Business Administration, Bilkent University, Turkey
}

\section{A R T I C L E I N F O}

\section{Article history:}

Received 20 January 2017

Received in revised form 2 May 2017

Accepted 23 May 2017

Available online 24 May 2017

\section{JEL classification:}

F31

F4

G1

Keywords:

Global financial crisis

Exchange rates

Volatility

Macroeconomic news

High-frequency data

\begin{abstract}
A B S T R A C T
We investigate the volatility reaction to macroeconomic news in major currency markets during the recent global financial crisis. We first present an alternative method for determining the changes in economic states by endogenously estimating crisis thresholds. Second, we assess which macroeconomic indicator gave the earliest warning signal for the upcoming contraction. Third, we investigate whether there is a systematic change in the volatility reaction of exchange rates to news during the crisis period. We find that the estimated logistic transition function based on the housing starts data exhibits the earliest warning signal compared to other indicators. Our results suggest that although volatility response to most news indicators is larger in expansion, currency market reaction to new home sales and Fed funds rate news is larger in the crisis period. We attribute this finding to the context-specific relevance of the housing and credit sectors in the evolution of the global financial crisis.
\end{abstract}

(c) 2017 Elsevier Inc. All rights reserved.

\section{Introduction}

In this paper, we investigate the intraday volatility reaction to macroeconomic news announcements during the recent global financial crisis. We focus on volatility reaction to news because macroeconomic news is an important contributor to volatility accounting for about a third of the total price variation in currency markets (Evans and Lyons (2003)).

Although many studies investigate the state-dependent impact of macroeconomic news on conditional mean returns (e.g. Andersen, Bollerslev, Diebold, \& Vega, 2003, 2007; Bauwens, Ben Omrane, \& Giot, 2005; Fatum, Hutchison, \& Wu, 2010; Faust, Rogers, Wang, \& Wright, 2007; Goldberg \& Grisse, 2013), the foreign exchange (FX) literature on the time-varying volatility reaction to macroeconomic news is rather sparse (two notable exceptions are Pearce \& Solakoglu, 2007 and

\footnotetext{
it The authors would like to thank Murray William and Peter Neczesny for providing the Hotspot FXi data.

* Corresponding author at: Department of Business Administration, Bilkent University, 06800 Ankara, Turkey.

E-mail addresses: wbenomrane@brocku.ca (W. Ben Omrane), tsavaser@bilkent.edu.tr (T. Savaşer).

1 Goodman School of Business, Brock University, 1812 Sir Isaac Brock Way, St. Catharines, ON, Canada.
}

Laakkonen \& Lanne, 2009). Although earlier studies document a relatively stable link between macroeconomic news announcements and exchange volatility, this relationship can become unstable over time due to fluctuations in economic activity or changes in investors' perception about the future economic outlook (as documented in other markets around the global financial crisis such as Égert \& Kočenda, 2014; Huang, 2015; Mishra, Moriyama, \& N'Diaye, 2014).

Motivated with this background, we aim to contribute to the literature in three ways. First, we present an alternative method for determining the changes in economic states, by endogenously estimating crisis thresholds using different macroeconomic fundamentals, a more efficient method compared to using exogenously determined crisis dates. Second, we assess which macroeconomic indicator provides the earliest warning signal for the upcoming crisis. Third, we examine whether there is a systematic change in the foreign exchange volatility response to macroeconomic news around the crisis period.

Our analysis employs the smooth transition regression for estimating logistic transition functions and determining endogenous thresholds, which is a procedure originally developed by Teräsvirta (1994). The endogenous estimation of the thresholds between different regimes is important because it removes the subjectivity associated with using exogenous dates (or values) for conducting event studies. In addition, this estimation of procedure allows for the possibility of gradual as well as abrupt transitions. 
The currencies we consider are the euro, pound and yen against the US dollar, the most actively traded currencies in the world. We focus on these major currency pairs because the two studies that we build on employ a subset of these currencies, allowing us to compare our results to the previous literature (Laakkonen \& Lanne, 2009; Pearce \& Solakoglu, 2007). We use 5-minute returns due to the fast return adjustment of exchange rates to macroeconomic news (Andersen et al., 2003, 2007). Since time-varying volatility reaction to news is likely to be particularly pronounced when state uncertainty is high, we focus our analysis on the recent global financial crisis period during which market uncertainty rose to unprecedented levels.

Our main results are the following: First, we find that crisis thresholds (i.e. start and end dates) vary significantly depending on the transition indicator used for the estimation of the transition logistic function. Second, using the housing starts release as the transition indicator in the estimated transition probability function provides the earliest signal of the upcoming crisis period. Third, we document that volatility response to news varies over time. Our findings reveal that, for the three currencies, on average, the volatility reaction to about $40 \%$ of the macroeconomic news announcements are larger during periods of economic growth. However, we also find that for about a third of the news announcements, the volatility reaction to news is larger in the crisis period. In particular, the volatility reaction to the new home sales and the Fed funds rate releases is consistently larger during the recent financial crisis.

While the larger volatility reaction to news in expansions is in line with the prediction of the Veronesi (1999) model, the latter finding regarding the stronger volatility reaction to new home sales and the Fed funds rate releases is consistent with context-specific relevance of the housing and credit markets in the evolution of the US financial crisis. That is, investors may rationally pay more attention to the announcements that contain information about the relevant risk factors (such as housing market related news during the crisis) driving interest rates and risk premia, which are critical in determining exchange rates (Faust et al., 2007). Taken together, our main results highlight the role of economic environment and the context-specific central bank policy decisions in generating time-varying news effects.

To check the robustness of our results, we repeat our analysis using endogenously estimated crisis thresholds that are based on alternative transition indicators. We also check if our results hold up when we focus on cumulative volatility reaction instead of contemporaneous volatility reaction to news. Reassuringly, the results remain unchanged when we implement these alternative specifications.

Overall, our findings suggest that investors and managers of multinational corporations that are exposed to FX risk as well as traders and institutional asset managers whose portfolios include international assets may find it useful to consider the time-varying impact of macroeconomic news on exchange rate volatility. In particular, our results can be used to design strategies to improve derivatives pricing where volatility is a key component and enhance risk management practices associated with international transactions.

The rest of the paper is organized as follows. We review the literature in Section 2, describe the data in Section 3 and explain the methodology in Section 4. Section 5 presents empirical analysis and discusses the results. Section 6 provides the robustness checks and the final section concludes.

\section{Literature review}

There is a large literature investigating the exchange rate reaction to news. Macroeconomic announcements, in particular, are an important determinant of exchange rates as they contribute to about a third of the price variation in FX markets (Evans \& Lyons, 2003). Related to the fast pace of the currency markets, most studies in this area use daily or intraday return data to investigate news effects. This is because the conditional mean return adjustment of exchange rates to news occurs within a few minutes after the news release (Andersen et al., 2003, 2007). Hence, using lower frequency returns may contaminate announcements' impact leading to biased news response coefficients.

The announcement literature investigating the currency markets has two main branches. The first branch focuses on the mean return adjustment of exchange rates to news while the second one focuses on the volatility reaction to news. Neely and Dey (2010) and Neely (2011) provide an excellent review of both segments. Our paper contributes to the second strand of the announcement literature in that we investigate the intraday volatility reaction to macroeconomic news releases in currency markets.

In particular, our motivation stems from the insight that volatility reaction to news might depend on a number of factors including the state of the business cycle and the heterogeneity of investors' expectations (especially with regards to the central bank's interest rate policy). In a recent study, for example, Huang (2015) examine the US bond and equity futures market volatility response to the first and second moments of news surprises around the global financial crisis. The research employs variance of news survey responses as an indicator of investor disagreement and the second moment of forecasted figures as a measure of uncertainty. The results indicate that volatility reaction is sensitive to business cycles, financial conditions and the zero-lower-bound constraint associated with the Fed's interest rate policy.

Related to the US central bank policy announcements, Mishra et al. (2014) document that the emerging markets' reaction to Fed's policy meeting releases also depends on economic fundamentals and financial conditions. Using daily return data, they show that countries with better fundamentals and greater financial depth experience less currency depreciation and smaller increase in government bond yields. In another related study, using daily data, Égert and Kočenda (2014) focus on three Central and Eastern European (CEE) countries' news and currencies (against the Euro) around the global financial crisis. They show that the currency returns exhibit a time-varying response to the macroeconomic news and central bank verbal communications emanating from the CEE countries. Their results indicate that while CEE macroeconomic news had significant effects on exchange rates during the pre-crisis period, only a few of those news had a similarly significant impact during the crisis. Interestingly, the responsiveness of exchange rates to verbal central bank communications become important only during the crisis period, pointing to context specific relevance of central bank policy actions during the crisis period when the bank's lender of last resort function gain prominence in investors' perception.

Our paper complements the state-dependent news effects documented in the aforementioned bond, equity and emerging markets studies, by presenting intraday evidence from the most liquid currency markets.

Although many intraday studies investigate the state-dependent impact of macroeconomic news on currency returns (e.g. Andersen et al., 2003, 2007; Bauwens et al., 2005; Fatum et al., 2010; Faust et al., 2007; Goldberg \& Grisse, 2013), the FX literature on the time-varying volatility reaction to macroeconomic news is relatively sparse (Neely, 2011). Two important exceptions include Pearce and Solakoglu (2007) and Laakkonen and Lanne (2009), both of which examine high frequency FX volatility reaction to macroeconomic news prior to 2005. Focusing on the period between 1999 and 2004, the latter study concludes that the effect of news on the euro-dollar volatility is larger in expansions. The former study, on the other hand, suggests that the mark-dollar volatility reaction to news is larger in contractions and that the yen volatility response is relatively stable between 1986 and 1996. In addition, Pearce and Solakoglu (2007) find no support for the hypothesis that volatility reacts differently to good versus bad news in the mark-dollar and yen-dollar markets whereas Laakkonen and Lanne (2009) find that in general bad news increases volatility more than good news.

Our paper adds to these studies in several respects. First, the two previous studies that examine time-variance in the intraday FX volatility reaction to news focus on the pre-2005 period. Our sample period, 
which includes the global financial crisis, offers a markedly different environment to test for the time-variance in news effects compared to the previous studies that focus on the well-known "Great Moderation" period, ${ }^{2}$ which exhibits very low macroeconomic volatility (Blanchard \& Simon, 2001). A more recent sample period allows us to test the external validity of the findings reported in these earlier studies since the news parameters estimated based on the Great Moderation period may reflect the stable macroeconomic conditions and policies of the time. Second, we extend the analysis to a larger number of news indicators and more currency pairs, which allow us to make comparison between the three most actively traded currencies whereas the previous two studies focus on one or two currencies with a more limited set of news indicators. Third, our empirical design enables us to assess which macroeconomic indicators exhibit the earliest warning signal for the upcoming crisis since we estimate logistic probability functions associated with various alternative transition variables (instead of using a single indicator). In addition, the estimated logistic function contributes to the literature by endogenously determining the crisis dates. Finally, we investigate the state-dependence of the volatility reaction by estimating individual news response coefficients for each announcement (rather than estimating a state-dependent news response coefficient for a single aggregated news indicator).

\section{Data}

To conduct our analysis, we use the 5-minute intraday exchange rate dataset, which is provided by Hotspot FXi. It consists of the euro-dollar, pound-dollar and yen-dollar currency pairs and spans five years from January 1, 2005 to December 31, 2009. We consider these currency pairs because they are the most actively traded currencies in the world. Additionally, the two studies that we build on also employ a subset of these currencies, allowing the comparability of our results to the previous literature (Laakkonen \& Lanne, 2009; Pearce \& Solakoglu, 2007). We use the post-2005 sample period because the two aforementioned studies focus on the pre-2005 period, which exhibits very low macroeconomic volatility (Blanchard \& Simon, 2001). Our more recent sample period includes the global financial crisis and allows us to test the external validity of the findings reported in earlier research.

We use intraday returns to analyze the volatility reaction to news because analyses that rely on daily FX returns may miss the variation in news response coefficients given the rapid response of exchange rate returns to news. Previous literature shows that the conditional mean adjustments of exchange rates to macroeconomic news occur very quickly, effectively amounting to jumps (Andersen et al., 2003, 2007). Therefore, in markets where return reaction to announcements is rapid, the use of wider return windows may contaminate announcement effects since longer intervals may include other events effects as well. This would reduce the public signal to noise ratio and introduce bias in the estimated news response coefficients. To mitigate this bias, many studies in the FX literature use high-frequency data to examine the announcement effects (e.g. Andersen et al., 2003, 2007; Bauwens et al., 2005; Fatum et al., 2010; Faust et al., 2007; Goldberg \& Grisse, 2013).

Our currency dataset contains tradable (as opposed to indicative) quotes for the bid and ask spot exchange rates. After filtering the data for outliers and other anomalies, we compute the midpoint price by taking the average of bid and ask prices. At the end of each 5-min interval, we use the closest previous tick to select the relevant price. Next, we calculate the return $\left(R_{t}\right)$ at time $t$ as the difference between the logarithm of the prices at times $t-1$ and $t$, multiplied by 100 . We define the trading day to start at 00:00 EST and end at 23:55 EST. We exclude weekends and holidays because of low trading activity. After these filters, the total number of returns in our sample reduces to 313,524 (Table 1).

\footnotetext{
2 The Great Moderation refers to the period between mid-1980s to the mid-2000s during which major macroeconomic fundamentals exhibited very low volatility (Blanchard \& Simon, 2001).
}

\section{Table 1}

Summary statistics.

This table reports the summary statistics of 5-minute exchange rate returns between January 1, 2005 and December 31, 2009. The dataset is provided by Hotspot FXi and contains tradeable bid-ask prices. The return $\left(R_{t}\right)$ at time $t$ is computed as the difference between the logarithms of the midpoint prices at times $t-1$ and $t$, multiplied by 100 . Trading days start at 00:00 EST and end at 23:55 EST. We also exclude weekends and holidays because of low trading activity, which reduces the total number of returns in our sample to 313,524 .

\begin{tabular}{llll}
\hline & \$/EUR returns & \$/GBP returns & \$/JPY returns \\
\hline Mean & 0.0001 & 0.00006 & -0.00003 \\
Median & 0.0000 & 0.0000 & 0.0000 \\
Maximum & 1.121 & 1.172 & 1.792 \\
Minimum & -1.129 & -1.157 & -1.805 \\
Std. dev. & 0.041 & 0.045 & 0.047 \\
Skewness & 0.069 & -0.071 & 0.336 \\
Kurtosis & 24.47 & 25.00 & 46.45 \\
\hline
\end{tabular}

The news dataset we employ includes the announced values of the US macroeconomic fundamentals along with the forecasts of the traders in anticipation of those releases. ${ }^{3}$ As standard in the announcement literature, to measure the unexpected component of each announcement, we calculate the standardized news surprise as the difference between the announced value of the indicator and its median forecast from the MMS survey divided by the sample standard deviation of this difference (Balduzzi, Elton, \& Clifton Green, 2001).

We cover all major US announcements that influence the currency markets following Andersen et al. (2003, 2007) and Fatum et al. (2010). The list includes the three GDP reports (advance, second and third), non-farm payroll employment, initial jobless claims, industrial production, capacity utilization, retail sales, personal income, consumer spending, construction spending, new home sales, durable goods orders, factory orders, business inventories, trade balance, producer price index, consumer price index, consumer confidence index, ISM index, housing starts, index of leading indicators, treasury budget and target federal funds rate releases (Table 2). These announcements correspond to nine major indicator categories: Real activity, employment, consumption, investment, net exports, government purchases, price, monetary policy and forward-looking news.

We consider various alternative measures of business cycle indicators to analyze the state-dependent news effects. Previously, McQueen and Roley (1993) use industrial production, Andersen et al. (2007) use employment rate and Veredas (2006) uses the Institute for Supply Management Survey (ISM) index as a measure of the business cycle. The ISM index is a monthly composite diffusion index that monitors conditions in national manufacturing based on the data from surveys of $>300$ manufacturing firms by the Institute of Supply Management. The index monitors employment, production inventories, new orders and supplier deliveries. Since it is a forward-looking indicator and is based on market expectations, Veredas (2006) suggests that this index is a better measure of the state of the economy compared to unemployment rate or industrial production. Therefore, in our analysis below, we use the ISM index as the main transition variable in the model to endogenously determine the thresholds between different states. The ISM index is equal to 50 when half of the respondents report good business conditions; an index value below 50 represents an economic contraction. For robustness check, however, we also consider the two other forward-looking macroeconomic variables, namely the housing starts and consumer confidence index, ${ }^{4}$ as alternative business condition indicators along with the non-farm payroll employment used in Andersen et al. (2007).

\footnotetext{
${ }^{3}$ All news and forecast survey data are collected by the Money Market Services (MMS) and provided by Action Economics.

${ }^{4}$ Fig. 1 illustrates graphically the four transition variable movements throughout the considered sample period.
} 
Table 2

US macroeconomic announcements.

There are 24 different announcements that are grouped into eight indicator categories: Real activity, employment, consumption, investment, net exports, government purchases, prices and forward-looking news. GDP reports are released quarterly. The target fed funds rate is released every six weeks. Initial jobless claims are announced weekly.

\begin{tabular}{|c|c|c|}
\hline Indicator group & Announcement & Source \\
\hline Real activity & GDP advance report & Bureau of Economic Analysis \\
\hline Real activity & GDP second report & Bureau of Economic Analysis \\
\hline Real activity & GDP third report & Bureau of Economic Analysis \\
\hline Real activity & Capacity utilization & Federal Reserve Board \\
\hline Real activity & Industrial production & Federal Reserve Board \\
\hline Real activity & Personal income & Bureau of Economic Analysis \\
\hline Real activity & Retail sales & Bureau of the Census \\
\hline Consumption & New home sales & Bureau of the Census \\
\hline Consumption & Personal expenditure & Bureau of Economic Analysis \\
\hline Investment & Business inventories & Bureau of the Census \\
\hline Investment & $\begin{array}{l}\text { Construction } \\
\text { spending }\end{array}$ & Bureau of the Census \\
\hline Investment & Durable orders & Bureau of the Census \\
\hline Investment & Factory orders & Bureau of the Census \\
\hline Price & $\begin{array}{l}\text { Consumer price } \\
\text { index }\end{array}$ & Bureau of Labor Statistics \\
\hline Price & Producer price index & Bureau of Labor Statistics \\
\hline Forward-looking & $\begin{array}{l}\text { Consumer } \\
\text { confidence }\end{array}$ & Conference Board \\
\hline Forward-looking & Housing starts & Bureau of the Census \\
\hline Forward-looking & ISM (manufacturing) & Institute for Supply Management \\
\hline Forward-looking & Leading indicators & Conference Board \\
\hline Employment & Initial claims & $\begin{array}{l}\text { Employment and Training } \\
\text { Administration }\end{array}$ \\
\hline Employment & Nonfarm payrolls & Bureau of Labor Statistics \\
\hline FOMC & Fed funds rate & Federal Reserve Board \\
\hline Net exports & Trade balance & Bureau of Economic Analysis \\
\hline Government & Treasury budget & Financial Management Service \\
\hline
\end{tabular}

\section{Methodology}

To investigate whether the volatility impact of the US macroeconomic news depends on the state of the economy, we use a two-step procedure. First, we estimate the pure announcement effect of all of the combined US macroeconomic news over the entire sample. Then, we compute the indicator-specific macroeconomic news effects on return volatility using the estimated transition probability calculated in the first stage. Hence, the transition probability estimated in the first stage serves as the endogenous threshold that allows us to examine the state-dependency of news effects in the second stage.

We begin our analysis by estimating the transition function, $G$, using the two-state logistic smooth transition regression (LSTR) model, introduced by Teräsvirta (1994):

$y_{t, n}=\alpha_{1}+\sum_{j=1}^{J} \beta_{j} \Gamma_{t, n-j}+\left\{\alpha_{2}+\sum_{j=1}^{J} \beta_{j}^{\prime} \Gamma_{t, n-j}\right\} G\left(\psi_{t, n}, \gamma, c\right)+u_{t, n}$

with $G\left(\psi_{t, n}, \gamma, c\right)=\frac{1}{1+\exp \left[-\gamma \prod_{k=1}^{K}\left(\psi_{t, n}-c_{k}\right)\right]}, \gamma>0$

where $y_{t, n}$ denotes the filtered exchange rate volatility on day $t$ and intraday time interval $n(n=1,2, \ldots N) . \Gamma_{t, n}$ is a vector of all of the combined US macroeconomic news announcements released over the sample period. $G$ represents the logistic transition function of the continuous transition variable $(\psi),{ }^{5}$ the shape parameter $(\gamma)$, the location parameter $(c)$, and transition function scale $(k) .{ }^{6}$ The transition function, $G$, allows us to account for the effect of an increase in the probability of being in a contraction (or expansion) period on a continuous

\footnotetext{
${ }^{5}$ We checked the effects of lagged variables and found no significant difference with the contemporaneous ones.

${ }^{6}$ The selection of $k$ is based on the model specification test suggested by Teräsvirta (1994). The result of the test suggests $k=1$, i.e. the logistic STR (LSTR1).
}

spectrum, hence capturing the direct effect of state uncertainty in our volatility framework.

To illustrate our methodology in this section, we use the ISM index as the transition variable. However, the analysis below also considers alternative transition variables such as non-farm payroll and housing starts. The model implies that there is a transition between two regimes when $G\left(\psi_{t, n}, \gamma, c\right)=0$ (tends to occur when $\left.\psi_{t, n}<c\right)$ or $G\left(\psi_{t, n}, \gamma, c\right)=1$ (tends to happen when $\psi_{t, n} \geq c$ ). For instance, an ISM index value $\left(\psi_{t, n}\right)$ below the level " $c$ " represents an economic contraction and hence implies that $G=0$. Here, the threshold level " $c$ " itself is endogenously determined as well.

A small (large) shape parameter $\gamma$ implies a smooth (sharp) transition between regimes. As $\gamma$ tends to infinity, the model converges to a switching regression and when $\gamma$ is not statistically different from zero, the model simplifies to a linear regression model. $\beta_{j}$ and $\left(\beta_{j}+\beta_{j}\right)$ represent the macroeconomic news effects on volatility during the contraction regime $\left(\psi_{t, n}<c\right)$ and expansion regime $\left(\psi_{t, n} \geq c\right)$ respectively. $J$ denotes the time length of news effect persistence where $j=1$ corresponds to the contemporaneous effect.

We compute the filtered exchange rate volatility through a sequential process following Andersen and Bollerslev (1998), and Laakkonen and Lanne (2009). First, we estimate the cyclical volatility component using Flexible Fourier Form (FFF) regression:

$$
\begin{aligned}
f_{t, n}= & \mu+\delta_{1} n+\delta_{2} n^{2}+\sum_{l=1}^{L} \lambda_{l} I_{l, t, n} \\
& +\sum_{p=1}^{P}\left(\delta_{c, p} \cos \left(\frac{2 \pi p}{N} n\right)+\delta_{s, p} \sin \left(\frac{2 \pi p}{N} n\right)\right)+\varepsilon_{t, n}, \text { and } f_{t, n} \\
= & 2 \operatorname{Ln} \frac{\left|R_{t, n}-\bar{R}\right|}{\sigma_{t} / \sqrt{N}}
\end{aligned}
$$

where $R_{t, n}$ denotes the intraday returns, $\bar{R}$ is the expected intraday returns. $\sigma_{t}$ represents the GARCH $(1,1)$ one day ahead volatility, ${ }^{7}$ and $N$ the number of time intervals per day. $I_{l}$ captures the seasonal pattern $l$ including the Japanese lunch, Japanese open, and the US late afternoon during the US daylight saving time. ${ }^{8}$ In order to capture the deterministic and time-varying seasonality components, we estimate the FFF estimation in sequential sub-periods of four weeks. ${ }^{9}$ We estimate the normalized intraday seasonality as:

$\hat{s}_{t, n}=\exp \left(\hat{f}_{t, n} / 2\right) / \bar{s}_{t, n}$

where $\hat{f}_{t, n}$ denotes the fitted values from Eq. (3) and $\bar{s}_{t, n}$ represents the average intraday seasonality. To compute the filtered returns, ${ }^{10}$ we divide the original returns $R_{t, n}$ by the normalized intraday seasonality:

$\hat{R}_{t, n}=\frac{R_{t, n}}{\hat{S}_{t, n}}$,

Then, we calculate the filtered exchange rate volatility as:

$y_{t, n}=2 \operatorname{Ln} \frac{\left|\hat{R}_{t, n}-\bar{R}\right|}{\sigma_{t} / \sqrt{N}}$.

We plot the autocorrelation coefficients of the original and filtered absolute returns in a five-day auto-correlogram in Fig. 2, which shows

\footnotetext{
7 We estimate the one-day-ahead volatility forecast using $\operatorname{AR}(2)-G A R C H(1,1)$ from January 2, 2000 through December 31, 2004.

8 To capture the seasonality pattern, we follow the methodology set out in Andersen and Bollerslev (1998) and Andersen et al. (2003). See Eq. (7) for the exact form of the polynomial structure.

${ }^{9}$ We also consider sub-periods of one and two weeks, but the estimated results were not statistically significant.

${ }^{10}$ See Andersen and Bollerslev (1998) for a more detailed explanation of the procedure.
} 


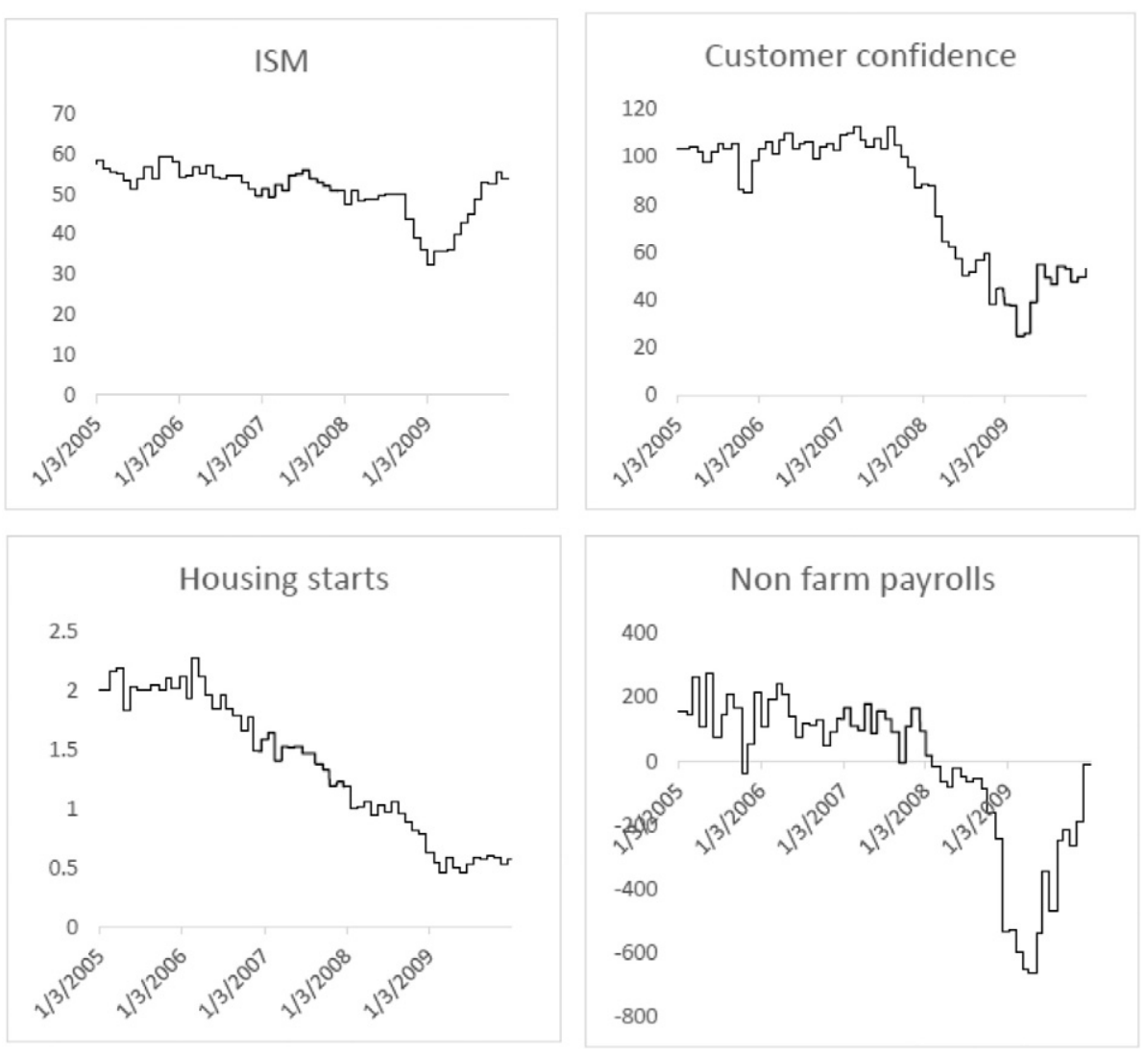

Fig. 1. Business cycle indicators.

that the FFF method filters most of the intraday seasonality in exchange rate volatility.

Previous studies show that the volatility impact of news is persistent and lasts for about $2 \mathrm{~h}$ (Andersen et al., 2003; Laakkonen and Lanne, 2009; Ben Omrane and Hafner, 2015; Bauwens et al., 2005; Dominquez and Panthaki, 2006). To control for the volatility persistence in our model, we impose a polynomial structure on the response patterns associated with $\beta_{j}$ and $\beta_{j}$, where $J$ denotes the response window $(j=1,2, \ldots, J)$. The polynomial specification ensures that the response patterns are fully incorporated within the response horizon $J^{11}$ :

$\lambda_{j}=\tau_{1}\left(1-\left(\frac{j}{J}\right)^{3}\right)+\tau_{2}\left(1-\left(\frac{j}{J}\right)^{2}\right) j+\tau_{3}\left(1-\left(\frac{j}{J}\right)\right) j^{2}$

Here, $\lambda_{j}$ represents the fitted values corresponding to the centered average absolute returns ${ }^{12}$ regression on the polynomial exogenous variables. As seen in Fig. 3, the estimated decay structure matches the actual average news impact pattern quite well.

To investigate the exchange rate response to different macroeconomic news surprises over the two regimes, we estimate both the return and volatility models. We model intraday returns $R_{t, n}$ as a linear

\footnotetext{
11 The response horizon includes a two-hour window plus the contemporaneous period $(J=25)$.

${ }^{12}$ Centered average absolute returns are computed as the average absolute returns at each time interval just after the news announcements minus the average absolute return computed over the whole sample.
}

function of lagged values of itself and macroeconomic news surprises:

$$
\begin{aligned}
R_{t, n}= & \theta_{1}+\vartheta_{i} \sum_{i=1}^{I} R_{t, n-i}+\sum_{q=1}^{Q} \sum_{j^{\prime}=1}^{J^{\prime}} \kappa_{q, j^{\prime}} S_{q, t, n-j^{\prime}} \\
& +\left\{\theta_{2}+\sum_{q=1}^{Q} \sum_{j^{\prime}=1}^{J^{\prime}} \kappa_{q, j^{\prime}}^{\prime} S_{q, t, n-j^{\prime}}\right\} \hat{G}\left(\psi_{t, n}, \gamma, c\right)+\nu_{t, n}
\end{aligned}
$$

$\mathrm{S}_{q}$ denotes the news surprise in indicator $q$ computed as the difference between the actual value of the news $\left(A_{q}\right)$ minus its median forecast $\left(\mathrm{F}_{q}\right)$ divided by the standard deviation of the difference $\left(\mathrm{A}_{q}-\mathrm{F}_{q}\right) . Q$ represents the 24 different types of US macroeconomic news indicators under analysis. We choose $I=2$ and $J^{\prime}=2$ based on the Schwarz and Akaike information criteria.

Finally, we examine the volatility response to macroeconomic news surprises using the following model based on Andersen et al. (2003):

$$
\begin{aligned}
\left|\nu_{t, n}\right|= & \eta_{1}+\omega \frac{\hat{\sigma}_{t}}{\sqrt{N}}+\sum_{q=1}^{Q} \sum_{j=1}^{J} \varphi_{q, j}\left|S_{q, t, n-j}\right| \\
& +\sum_{p=1}^{P}\left(\delta_{c, p} \cos \left(\frac{2 \pi p}{N} n\right)+\delta_{s, p} \sin \left(\frac{2 \pi p}{N} n\right)\right)+\sum_{l=1}^{L} \lambda_{l}^{\prime} I_{l, t, n} \\
& +\left\{\eta_{2}+\sum_{q=1}^{Q} \sum_{j=1}^{J} \varphi_{q, j}^{\prime}\left|S_{q, t, n-j}\right|\right\} \hat{G}\left(\psi_{t, n}, \gamma, c\right)+\chi_{t, n} .
\end{aligned}
$$

where the first term on the right hand side represents the constant vector; the second term denotes the one-step ahead volatility GARCH $(1,1)$ and the third component captures the effect of the absolute news surprise on volatility. The state-dependence of the volatility response to macroeconomic news is captured by the interaction of the estimated logistic transition function $(\hat{G})$ with the absolute news surprise term. Lastly, $\chi_{t, n}$ represents the residuals from the model. 


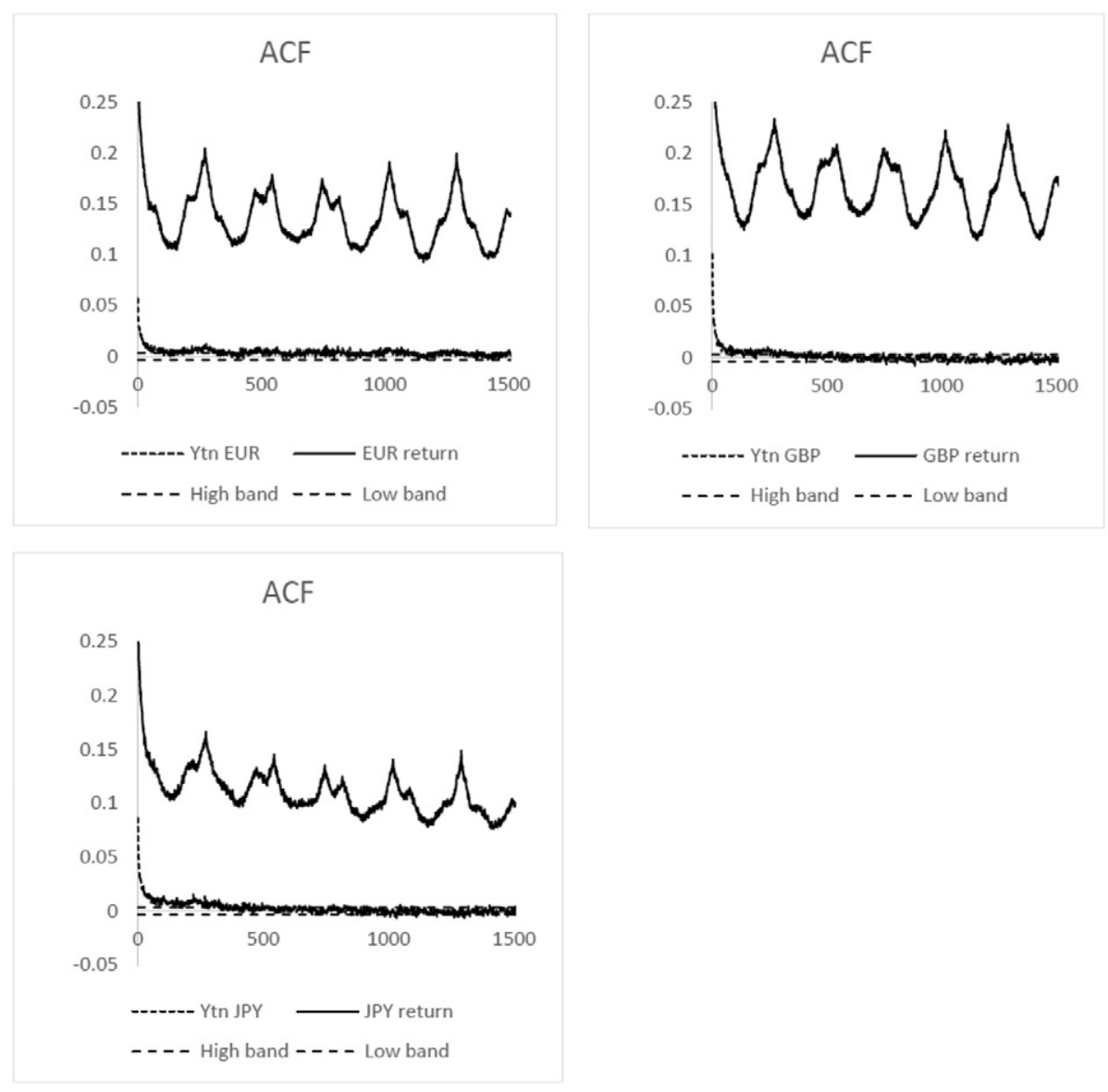

Fig. 2. Autocorrelation coefficients of the original and filtered absolute 5 -minute returns $\left(y_{t, n}\right)$

\section{Empirical analysis and discussion of results}

This section presents and discusses the empirical results from our analysis. In the first part, we present the estimated logistic transition probability functions (Eqs. (1) and (2)) for various different indicators to determine endogenous crisis thresholds in FX markets over our sample period. In the second part, we investigate whether there is a systematic change in the volatility reaction of exchange rates to news. However, instead of using exogenous crisis thresholds, we use the endogenously determined thresholds in the volatility model (Eq. (9)), and present the estimated news response coefficients. The third subsection discusses our results.

\subsection{Endogenous crisis thresholds}

First, we begin by discussing the estimated parameters from the smooth transition regression model, which employs the ISM index as the transition variable (Table 3). Our estimation suggests that the smoothness (or slope) parameter of the logistic function, $\gamma$, is statistically significantly different from zero at the one percent level and is approximately equal to four for the euro and pound-dollar exchange rates and six for the yen-dollar currency pair. The slope parameter $\gamma$ indicates how rapidly the transition between different states takes place. While a moderate value of $\gamma=2$ indicates a smooth move between regimes (i.e. a transition), an estimated value of $\gamma=4$ suggests a relatively abrupt move (i.e. a switch).

To illustrate this result graphically, we plot the estimated transition functions against time in Figs. 4, 5 and 6. We find that the logistic transition functions based on the ISM index portray a steep regime change at the beginning of 2008 followed by a relatively gradual improvement in the second quarter of 2008. The logistic function reflects another switch into a contraction state in the fourth quarter of 2008 that lasts until September 2009. We compare the timing of the estimated logistic function with that of the NBER recession dates. According to the NBER, the Great Recession started in January 2008 and ended at the end of June 2009. The transition periods estimated by the ISM logistic function align with the NBER business cycle dates, though the model predicts an interim improvement in economic state within the NBER recession window, which then reverts back into contraction in the third quarter of 2008.

To assess which macroeconomic indicators exhibit the earliest warning signal for the upcoming crisis over our sample period and to check whether transition dynamics change depending on the choice of transition variable, we consider a set of alternative indicators suggested by the previous literature. In their analysis of the state-dependent news effects, Andersen et al. (2003) use the non-farm payroll employment to partition the sample into recession and expansion periods. Laakkonen and Lanne (2009) and Veredas (2006), on the other hand, use the ISM index and suggest that the forward-looking variables perform better as transition indicators. Following this literature, we include the nonfarm payroll employment and two additional forward-looking indicators, the housing starts and consumer confidence index, to our list of transition variables.

As seen in Figs. 4, 5 and 6, consumer confidence reveals switches in all three markets similar to the ones estimated based on the ISM index. Logistic functions based on employment figures indicate abrupt moves, but the deterioration and improvement in market conditions occur later compared to the NBER recession start and end dates. This pattern is consistent with the slower adjustment in labor markets and the jobless recovery experienced following the Great Recession (Elsby, Hobijn, \& Sahin, 2010). In addition, the thresholds estimated based on housing starts and consumer confidence data indicate that the crisis in currency 


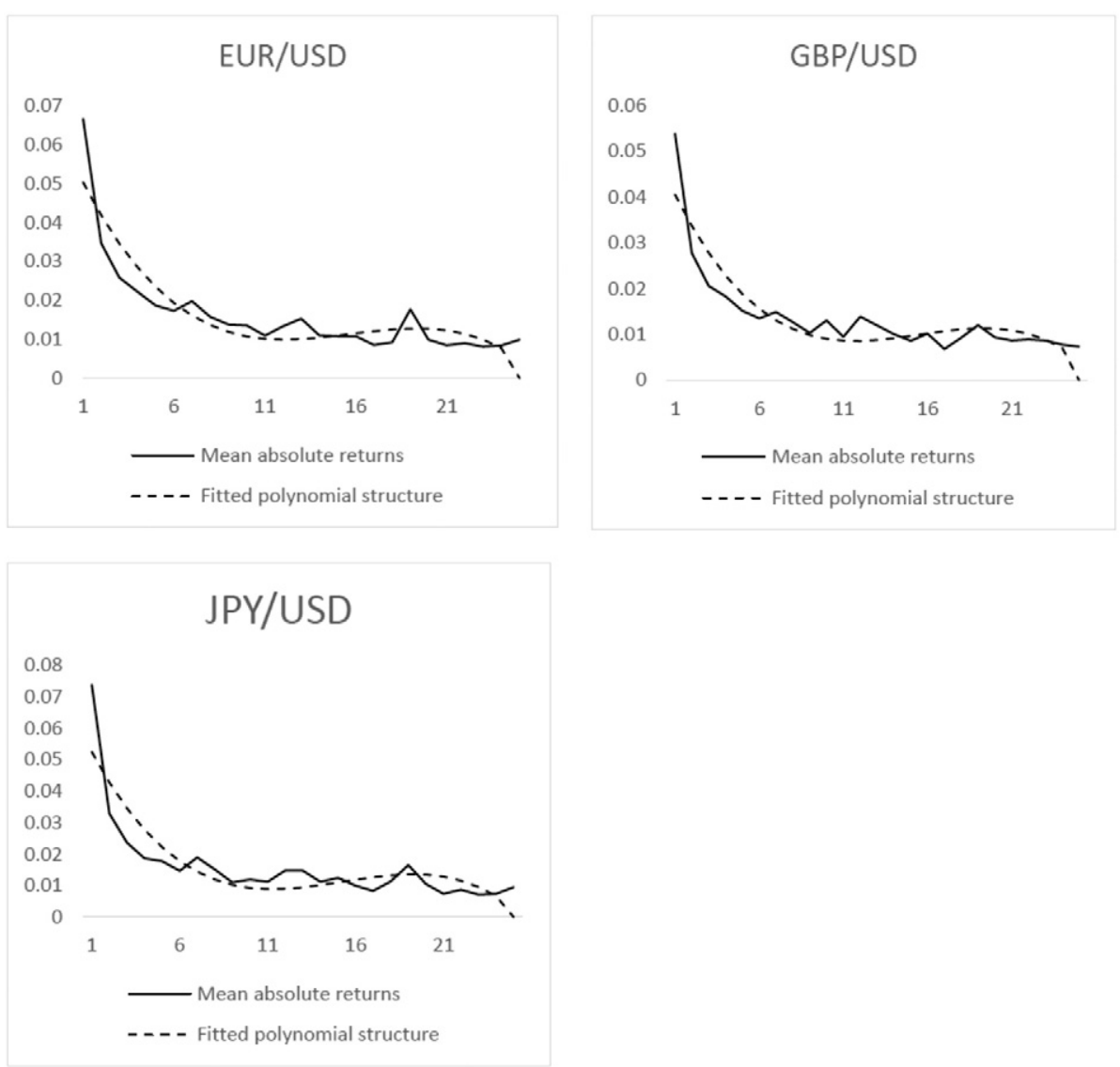

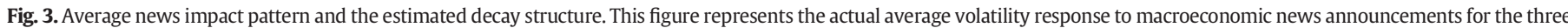
currency pairs (euro, pound, yen vs the US dollar) and the estimated polynomial decay structure based on Eq. (7).

markets continues throughout 2009 whereas the estimated thresholds based on employment and manufacturing index data suggest that the crisis in the major FX markets ends by late 2009.

In contrast to the logistic functions based on consumer confidence and non-farm payroll employment figures, the housing starts reveal a more gradual and early deterioration in economic conditions in the euro-dollar and pound-dollar markets. Consistent with this finding, the logistic functions estimated based on the housing starts data have smaller slope parameters 2.7 and 3.8 respectively (Table $3 \mathrm{~A}$ and $\mathrm{B}$ ) in the euro and pound markets indicating a smoother transition between

Table 3

Smooth transition model: Estimation results based on alternative transition indicators.

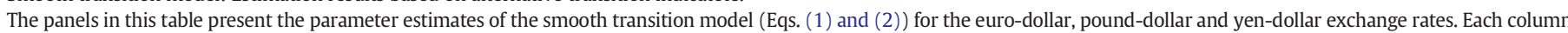

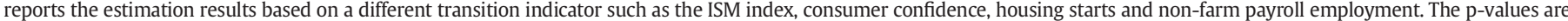
reported next to the estimated parameters.

\begin{tabular}{|c|c|c|c|c|c|c|c|c|}
\hline & ISM index & p-Value & Consumer confidence & p-Value & Housing starts & p-Value & Non-farm payroll & p-Value \\
\hline \multicolumn{9}{|c|}{ Panel A. EUR/USD estimation results for Eqs. (1) and (2) } \\
\hline$\alpha 1$ & 3.80 & 0.00 & -1.87 & 0.00 & -1.86 & 0.00 & -1.86 & 0.00 \\
\hline$\beta$ & 0.71 & 0.00 & 0.97 & 0.00 & 0.87 & 0.00 & 0.83 & 0.00 \\
\hline$\alpha 2$ & -0.09 & 0.00 & -0.09 & 0.00 & -0.11 & 0.00 & -0.09 & 0.00 \\
\hline$\beta^{\prime}$ & 1.00 & 0.00 & 0.82 & 0.00 & 1.04 & 0.00 & 0.90 & 0.00 \\
\hline$\gamma$ & 3.80 & 0.01 & 10.44 & 0.07 & 2.72 & 0.02 & 8.12 & 0.02 \\
\hline$c$ & -1.94 & 0.01 & 9.70 & 0.00 & -0.03 & 0.69 & -8.80 & 0.59 \\
\hline \multicolumn{9}{|c|}{ Panel B. GBP/USD estimation results for Eqs. (1) and (2) } \\
\hline$\alpha 1$ & 3.85 & 0.00 & -1.82 & 0.00 & -1.82 & 0.00 & -1.82 & 0.00 \\
\hline$\beta$ & 0.56 & 0.00 & 0.67 & 0.00 & 0.70 & 0.00 & 0.61 & 0.00 \\
\hline$\alpha 2$ & -0.10 & 0.00 & -0.09 & 0.00 & -0.11 & 0.00 & -0.09 & 0.00 \\
\hline$\beta^{\prime}$ & 0.88 & 0.00 & 0.83 & 0.00 & 0.86 & 0.00 & 0.84 & 0.00 \\
\hline$\gamma$ & 4.08 & 0.01 & 4.01 & 0.16 & 3.87 & 0.05 & 6.99 & 0.04 \\
\hline$c$ & -1.24 & 0.09 & 0.26 & 0.96 & -0.02 & 0.81 & -27.72 & 0.18 \\
\hline \multicolumn{9}{|c|}{ Panel C. JPY/USD estimation results for Eqs. (1) and (2) } \\
\hline$\alpha 1$ & 3.73 & 0.00 & -1.92 & 0.00 & -1.93 & 0.00 & -1.92 & 0.00 \\
\hline$\beta$ & 0.95 & 0.00 & 0.88 & 0.00 & 1.19 & 0.00 & 0.94 & 0.00 \\
\hline$\alpha 2$ & -0.09 & 0.00 & -0.10 & 0.00 & -0.12 & 0.00 & -0.10 & 0.00 \\
\hline$\beta^{\prime}$ & 0.68 & 0.00 & 0.87 & 0.00 & 0.61 & 0.00 & 0.77 & 0.00 \\
\hline$\gamma$ & 6.22 & 0.12 & 2.78 & 0.10 & 4082.62 & 0.99 & 7.62 & 0.05 \\
\hline$c$ & -2.16 & 0.00 & 68.77 & 0.00 & 1.52 & 0.94 & -49.98 & 0.02 \\
\hline
\end{tabular}



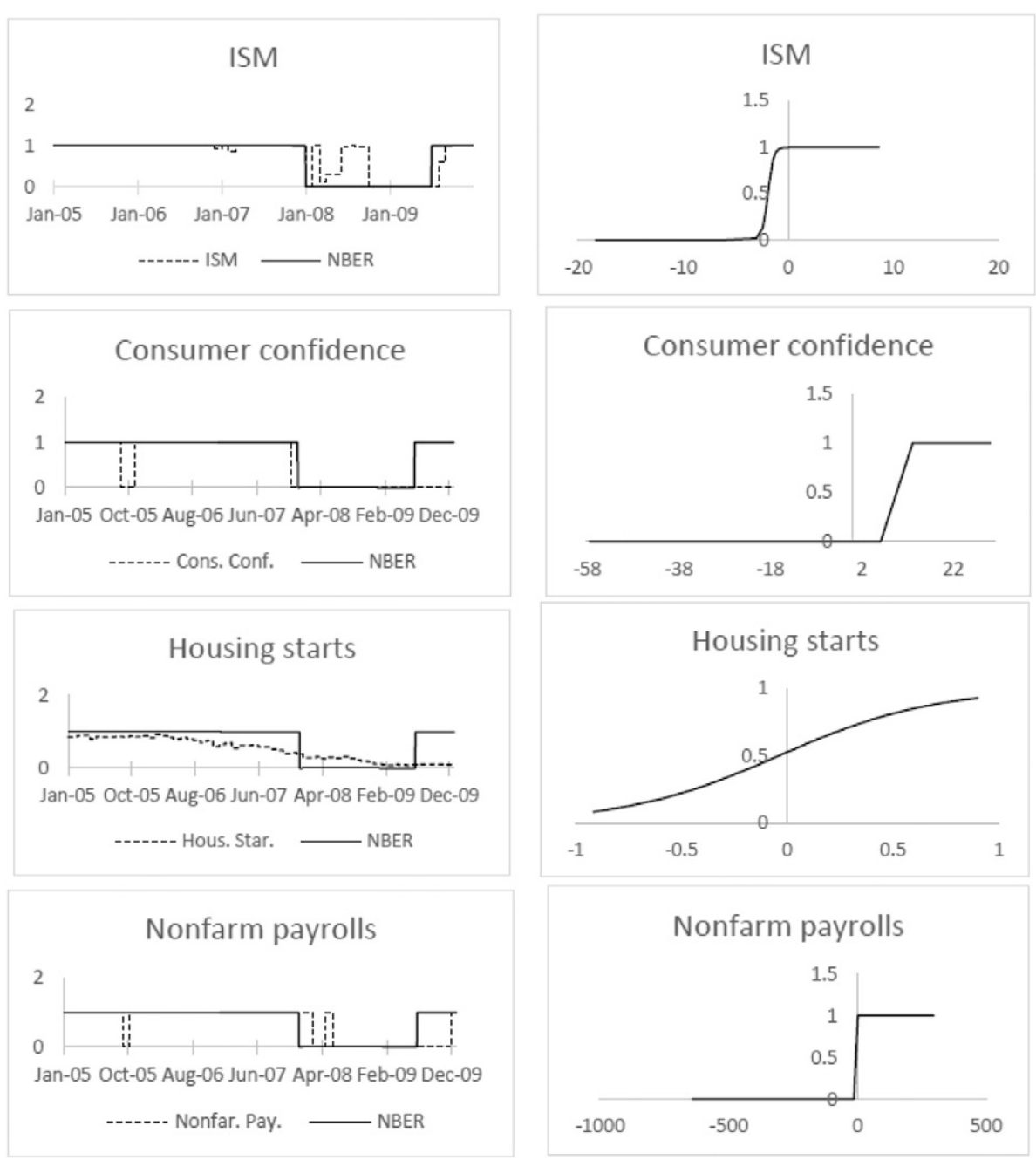

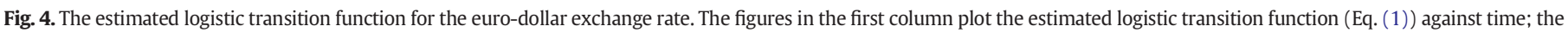

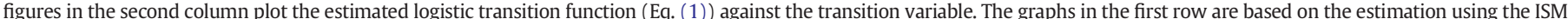

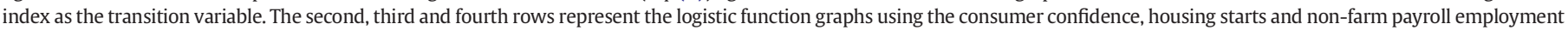
respectively. The solid line represents the NBER business cycle dates.

states. The estimated transition function in yen-dollar also shows early signs of contraction, however, unlike euro and pound, yen portrays a switch into the contraction state in the first quarter of 2007. The distinct pattern associated with yen is likely due to yen's own safe-haven currency status. Yen has been the "safest" of safe haven currencies during the recent global financial crisis. In fact, Fatum et al. (2016) illustrate that only the yen appreciated consistently against the dollar during the crisis regardless of the prevailing market uncertainty level. In line with their results, we find the state uncertainty probabilities estimated for the euro and pound markets to be more sensitive to the conditions in the US housing sector, displaying earlier and more gradual signs of deterioration, compared to the transition probabilities associated with the yen market.

\subsection{State-dependence in news effects}

In the second part of our analysis, we investigate whether the news effects are in fact state-dependent. To conduct the first-pass analysis of state-dependence, we turn to Table 3, where we report the estimated parameters from Eqs. (1) and (2). In the estimated smooth transition regression model, the coefficient $\beta$ represents the effect of the aggregate news indicator $(\Gamma)$ during the crisis period and $\beta+\beta^{\prime}$ captures the effect of the combined news indicator $(\Gamma)$ during the expansionary period. When $\beta^{\prime}$ is significantly different from zero, we conclude that the volatility response to macroeconomic news is state-dependent. Our results reveal that both $\beta$ and $\beta^{\prime}$ are positive and statistically significant, which suggests that macroeconomic news increases volatility and that this increase is more substantial during the expansion period compared to the crisis period (Table 3 ). This result holds for all logistic functions regardless of the transition variable used in the estimation procedure and suggests that the volatility reaction to aggregate news decrease as state uncertainty increases beyond an endogenously determined threshold level.

Next, in order to examine the state-dependence pattern in more detail, we estimate the contemporaneous volatility response to the individual news announcements (as opposed to the combined news aggregate) across different regimes. Table $4 \mathrm{~A}$ presents the volatility response coefficients based on the estimation of Eq. (9) using ISM as the transition indicator. In this specification, $\phi$ represents the contemporaneous volatility response coefficient in the crisis period and $\left(\phi+\phi^{\prime}\right)$ represents the corresponding coefficient in the expansion period.

For the euro market (pound and yen respectively), we find that 13 (10 and 8 ) out of the total of 24 news items are associated with a volatility response that is statistically significantly larger in expansion compared to the crisis, while 8 ( 5 and 10 ) news items are associated with a larger reaction in the crisis period. The coefficients associated with the remaining 3 ( 9 and 6 ) news items reveal that the volatility response does not depend on the level of state of the economy. Overall, for the 

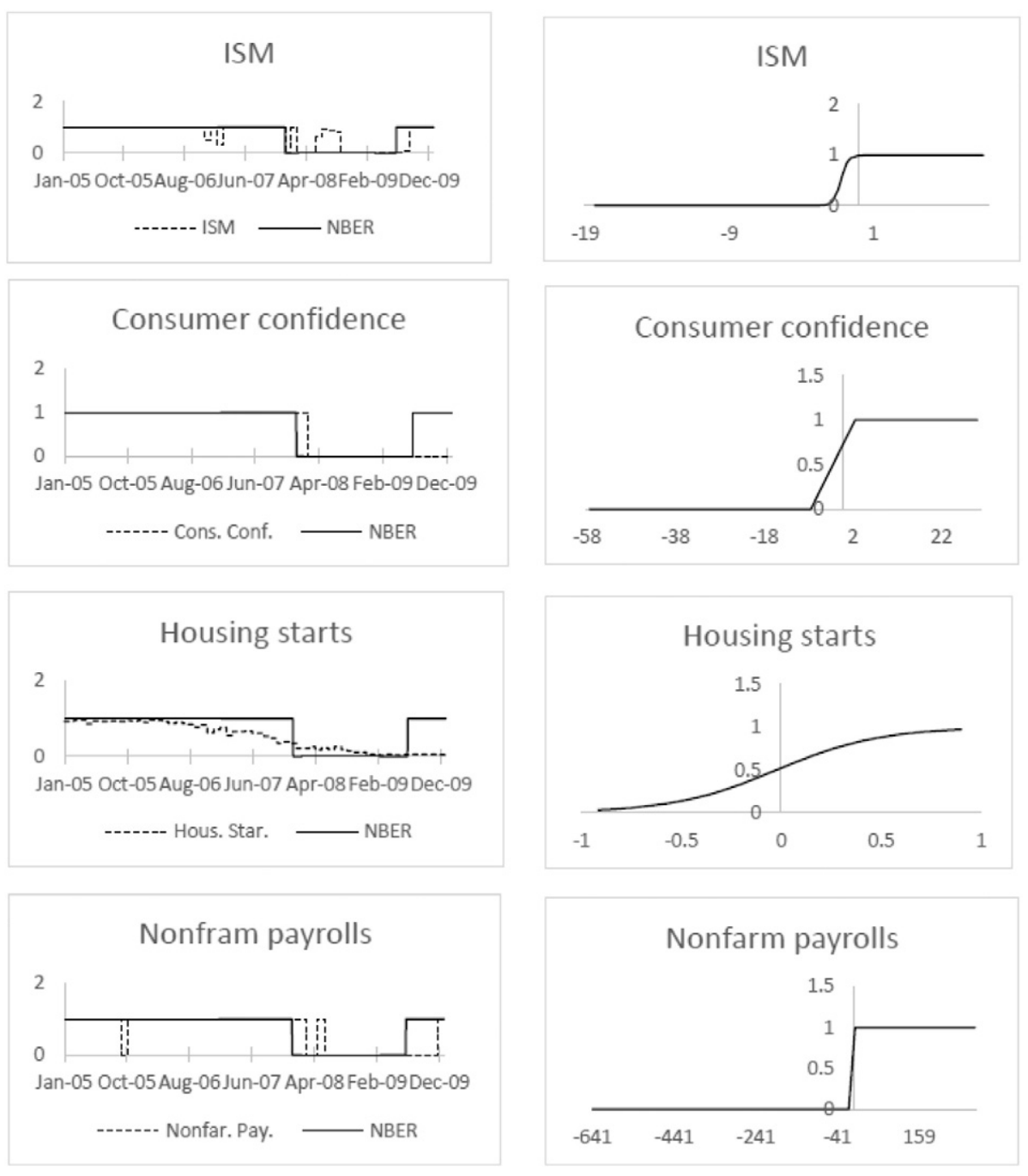

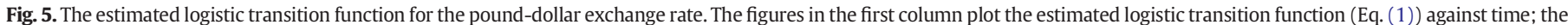

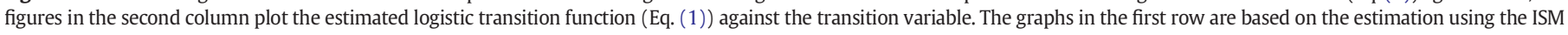

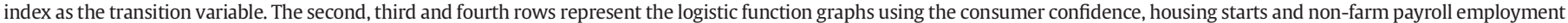
respectively. The solid line represents the NBER business cycle dates.

three currencies studied, on average, the magnitude of the volatility response is larger in expansions for about $43 \%$ of the 24 news items under analysis. The volatility reaction is larger in the crisis period for about a third of the news items, and market response to about a quarter of the news items exhibit time-invariant properties.

When there are differences in volatility reaction across different states of the economy, these differences are economically meaningful. In the yen-dollar market, for instance, a one standard deviation increase in the unanticipated component of the non-farm payroll announcement leads to an immediate 11 basis points jump in volatility during the expansion whereas the same increase in the announcement surprise is associated with an eight basis point increase in the crisis period, a difference that is statistically significant at the one percent level (Table $4 \mathrm{~A})$. This is an economically significant magnitude given the conventional dollar-yen interdealer spreads, which average around 1.5 basis points over our sample period (Mancini, Ranaldo, \& Wrampelmeyer, 2013).

In particular, we find that the non-farm payroll, GDP advance release, retail sales and CPI announcements are consistently associated with a volatility reaction that is larger in expansion compared to the crisis period in all three markets. In contrast, the volatility response to new home sales and Fed funds rate is consistently larger in the crisis period. For instance, in the yen-dollar market, a one standard deviation increase in the unanticipated component of the new home sales announcement lead to a one basis point jump in volatility during the expansion period whereas the same increase in the announcement surprise is associated with a seven basis point increase in the crisis period, a difference that is statistically significant at the one percent level (Table 4A). These results also hold for the euro and pound-dollar exchange rates and are robust to using alternative indicators as transition variables in the estimation of logistic functions (Tables $4 \mathrm{~B}$ and $4 \mathrm{C}$ ).

\subsection{Discussion of results}

The results from the first part of our analysis suggest that the crisis thresholds (i.e. start and end dates) vary significantly depending on the transition indicator used for the estimation. When we use consumer confidence, non-farm payroll employment or manufacturing (ISM) index to determine the transition dynamics, we find that the crisis in the major currency markets began in the first quarter of 2008, which overlaps with the recession start date determined by the National Bureau of Economic Research (NBER). However, when we estimate the regime thresholds based on housing data, we find that the first signs of the crisis date back to the first quarter of 2007, suggesting that the housing starts data exhibit the earliest signal of the upcoming increase in state uncertainty. We attribute this sensitivity to the information content of 


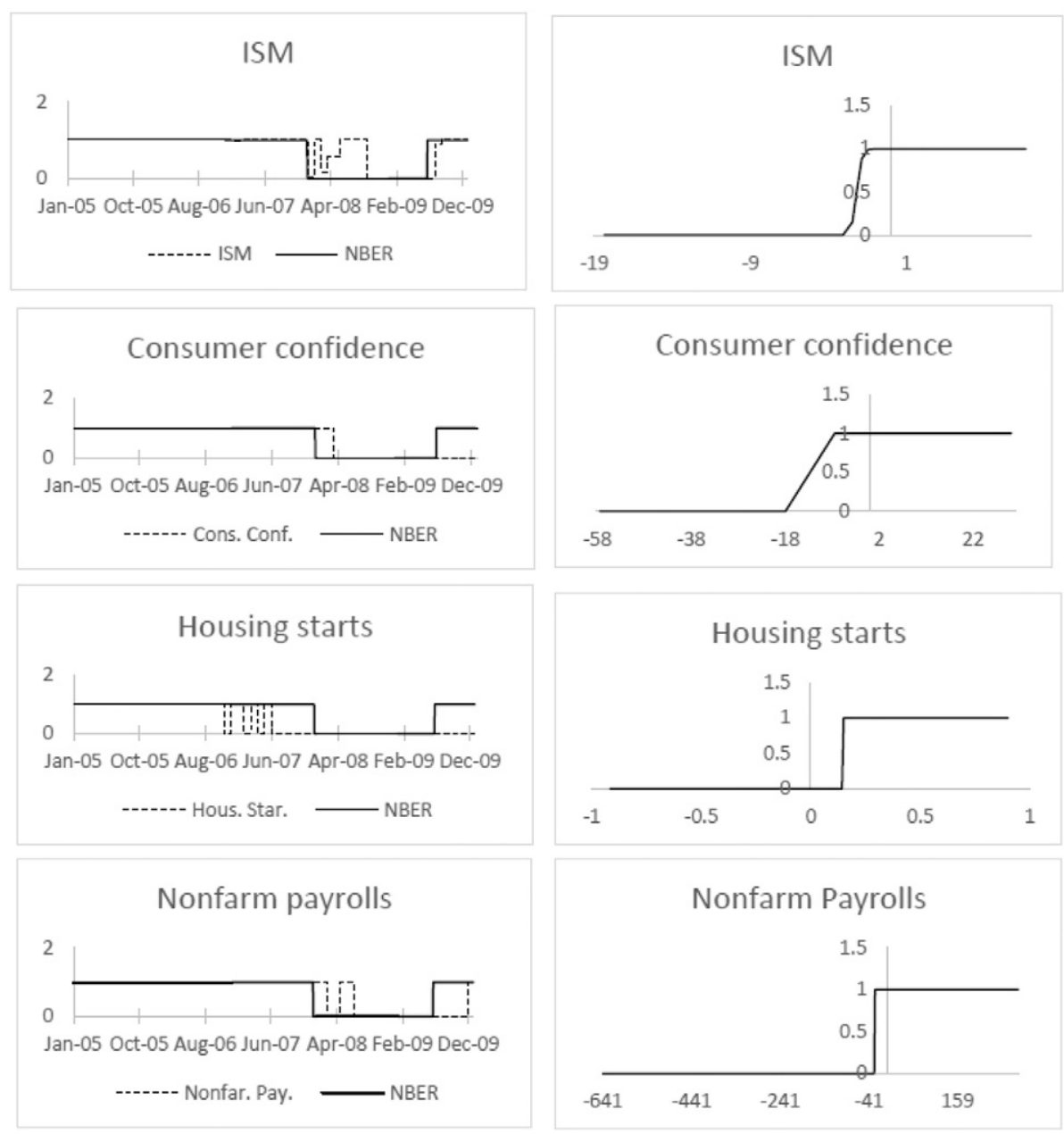

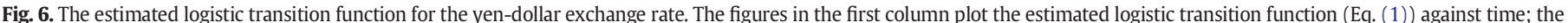

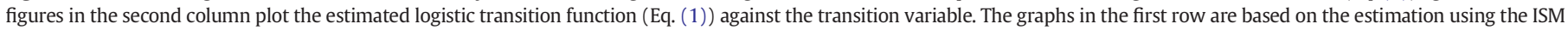

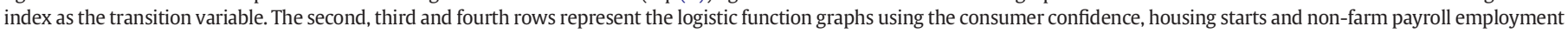
respectively. The solid line represents the NBER business cycle dates.

the macroeconomic indicator used as the transition variable in the logistic function. Considering the role of the US housing sector in the evolution of the global financial crisis, the forward-looking housing indicator contains market specific data related to the source of the crisis. Accordingly, the logistic function estimated using the housing starts indicator reflects an earlier transition compared to the other forward-looking indicators such as the ISM and the consumer confidence index, which provide more general information about the state of the manufacturing sector and the overall economic sentiment.

In their investigation of the effects of the recent US financial crisis on FX markets, Melvin and Taylor (2009) assume August 2007 and Fratzscher (2009) assumes July 2008 as the start date of the crisis in FX markets. Our results based on housing starts data suggest that the crisis definition employed in Melvin and Taylor (2009) is more likely to capture the crisis effects fully. In addition, according to the endogenously determined thresholds based on housing starts and consumer confidence data, we find that the crisis in currency markets continues throughout 2009 whereas the estimated thresholds based on employment and manufacturing index data suggest that the crisis in the major FX markets ends by late 2009.

The second part results indicate that the impact of news on exchange rate volatility varies over time. When we use an aggregate news indicator, we find that macroeconomic news, on average, tend to generate a larger reaction in expansions. When we zoom in and investigate volatility reaction to individual news indicators (as opposed to an aggregate news indicator), we find that this result holds for about $40 \%$ of the news indicators. Yet, there are specific announcements such as the new home sales and Fed funds rate announcements that generate a larger volatility impact during the recent financial crisis.

The larger volatility reaction to news in expansions is in line with the Veronesi (1999) model, which predicts larger asset return reaction to bad news in expansions and more muted reaction to news in recessions. It is also consistent with the conjecture that investors pay less attention to macroeconomic news when the relationship between these announcements and the economic outlook is more uncertain (Ehrmann, Osbat, Strasky, \& Uusküla, 2013). Another possible explanation is that increased uncertainty regarding economic conditions may shift the central bank priorities, leading to a change in the investors' perception of future monetary policy. For instance, due to the Fed's financial stability mandate, investors may expect it to react less strongly to positive macro news when risk is elevated. Through interest parity condition and monetary policy reaction function, the updated expectations regarding the future interest rate path can influence how exchange rates react to macroeconomic news (Gürkaynak, Sack, \& Swanson, 2005; Swanson \& Williams, 2013, 2014; Goldberg \& Grisse, 2013), ultimately weakening the reaction of bond and currency markets to macroeconomic news in crisis periods.

We also confirm the external validity of the state-dependent news effects documented in Laakkonen and Lanne (2009), which focus on the euro-dollar exchange rate during the 1999-2004 period. However, while Laakkonen and Lanne (2009) find statistically significant parameter estimates for $\beta$ and $\beta^{\prime}$, the slope and location parameters ( $\gamma$ and 
Table 4A

Contemporaneous volatility response (transition indicator: ISM index).

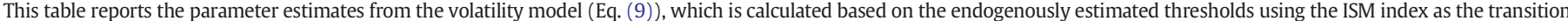

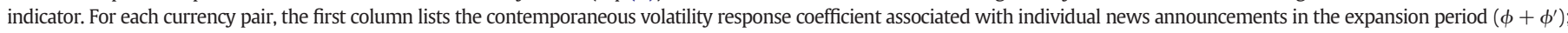

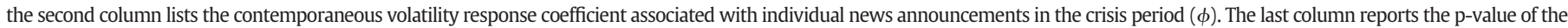
coefficient equality test. ${ }^{*},{ }^{* *},{ }^{* * *}$ denote statistical significance at $10 \%, 5 \%, 1 \%$ level respectively.

\begin{tabular}{|c|c|c|c|c|c|c|c|c|c|}
\hline \multirow{2}{*}{$\begin{array}{l}\text { ISM } \\
\text { News variables }\end{array}$} & \multicolumn{3}{|l|}{ USD/EUR } & \multicolumn{3}{|l|}{ USD/GBP } & \multicolumn{3}{|l|}{ USD/JPY } \\
\hline & Expans. & Crisis & Pdiff & Expans. & Crisis & Pdiff & Expans. & Crisis & Pdiff \\
\hline Capacity utilization & $0.015^{* * *}$ & $0.021^{* * *}$ & 0.48 & $0.008^{*}$ & $0.017^{* * *}$ & 0.93 & $0.015^{* * *}$ & $0.037^{* * *}$ & 0.66 \\
\hline GDP advanced & $0.171^{* * *}$ & -0.004 & 0.00 & $0.105^{* * *}$ & 0.001 & 0.00 & $0.215^{* * *}$ & -0.006 & 0.00 \\
\hline GDP second & $0.022^{* * *}$ & -0.005 & 0.00 & $0.018^{* * *}$ & -0.001 & 0.00 & $0.014^{* *}$ & $0.020^{* * *}$ & 0.60 \\
\hline GDP third & $0.012^{* * *}$ & $-0.026^{* * *}$ & 0.00 & $0.007^{*}$ & -0.012 & 0.05 & 0.003 & $-0.032^{* * *}$ & 0.02 \\
\hline Industrial prod. & -0.004 & $-0.009^{*}$ & 0.93 & -0.006 & $-0.007^{*}$ & 0.64 & -0.004 & $-0.032^{* * *}$ & 0.10 \\
\hline Personal income & 0.002 & $-0.016^{* * *}$ & 0.01 & -0.001 & 0.000 & 0.66 & -0.003 & $0.015^{* *}$ & 0.02 \\
\hline Retail sales & $0.037^{* * *}$ & $0.027^{* * *}$ & 0.00 & $0.025^{* * *}$ & $0.018^{* * *}$ & 0.00 & $0.043^{* * *}$ & $0.019^{* * *}$ & 0.00 \\
\hline New home sales & 0.003 & $0.033^{* * *}$ & 0.01 & 0.003 & $0.012^{*}$ & 0.45 & $0.012^{* * *}$ & $0.066^{* * *}$ & 0.00 \\
\hline Personal exp. & $0.011^{* * *}$ & 0.005 & 0.05 & $0.008^{* * *}$ & -0.007 & 0.00 & $0.007^{* * *}$ & $-0.021^{* * * *}$ & 0.00 \\
\hline Business invent. & 0.004 & $-0.014^{* * *}$ & 0.00 & 0.001 & -0.001 & 0.60 & 0.001 & $0.022^{* * *}$ & 0.01 \\
\hline Construction sp. & $0.021^{* * *}$ & $0.016^{* * *}$ & 0.00 & $0.009^{* * *}$ & $0.017^{* * *}$ & 0.82 & $0.013^{* * *}$ & $0.015^{* * *}$ & 0.22 \\
\hline Durable orders & $0.024^{* * *}$ & $0.015^{* * *}$ & 0.00 & $0.012^{* * *}$ & $0.015^{* * *}$ & 0.14 & $0.022^{* * *}$ & 0.009 & 0.00 \\
\hline Factory orders & $0.007^{* *}$ & $0.006^{*}$ & 0.27 & 0.001 & $0.010^{* * *}$ & 0.17 & $0.008^{* * *}$ & $0.011^{* * *}$ & 0.53 \\
\hline CPI & $0.035^{* * *}$ & $0.018^{* * *}$ & 0.00 & $0.022^{* * *}$ & 0.002 & 0.00 & $0.034^{* * * *}$ & $0.014^{* * *}$ & 0.00 \\
\hline PPI & $0.016^{* * *}$ & -0.007 & 0.00 & $0.011^{* * *}$ & $-0.006^{*}$ & 0.00 & $0.007^{* * *}$ & $0.044^{* * *}$ & 0.00 \\
\hline Cons. confidence & $0.021^{* * *}$ & 0.004 & 0.00 & $0.007^{* *}$ & $0.009^{* * *}$ & 0.47 & $0.016^{* * *}$ & $0.014^{* * *}$ & 0.03 \\
\hline Housing starts & $0.015^{* * *}$ & -0.008 & 0.00 & $0.007^{* * *}$ & -0.004 & 0.01 & $0.012^{* * *}$ & $0.012^{*}$ & 0.24 \\
\hline ISM & $0.023^{* * *}$ & $0.018^{* * *}$ & 0.00 & $0.016^{* * *}$ & $0.018^{* * *}$ & 0.03 & $0.032^{* * *}$ & $0.015^{* * *}$ & 0.00 \\
\hline Leading indic. & 0.000 & $0.012^{* * *}$ & 0.10 & -0.001 & $0.011^{* * *}$ & 0.02 & -0.001 & $0.007^{*}$ & 0.24 \\
\hline Initial claims & $0.022^{* * *}$ & $0.023^{* * *}$ & 0.00 & $0.011^{* * *}$ & $0.008^{* * *}$ & 0.00 & $0.021^{* * *}$ & $0.023^{* * *}$ & 0.00 \\
\hline Nonfarm payroll & $0.099^{* * *}$ & $0.074^{* * *}$ & 0.00 & $0.067^{* * *}$ & $0.060^{* * *}$ & 0.00 & $0.108^{* * *}$ & $0.079^{* * *}$ & 0.00 \\
\hline Fed funds rate & $0.059^{* * *}$ & $0.064^{* * *}$ & 0.00 & $0.040^{* * * *}$ & $0.047^{* * *}$ & 0.00 & $0.049^{* * *}$ & $0.068^{* * *}$ & 0.00 \\
\hline Trade balance & $0.060^{* * *}$ & 0.005 & 0.00 & $0.035^{* * *}$ & $0.008^{* * *}$ & 0.00 & $0.054^{* * *}$ & -0.004 & 0.00 \\
\hline Treasury budget & $0.006^{*}$ & $0.040^{* * *}$ & 0.00 & 0.002 & $0.034^{* * *}$ & 0.00 & $0.008^{* *}$ & $0.035^{* * *}$ & 0.03 \\
\hline
\end{tabular}

c, respectively) in their analysis are statistically insignificant at the five percent level.

Our finding regarding the stronger volatility reaction to new home sales and the Fed funds rate releases is consistent with context-specific relevance of the housing and credit markets in the evolution of the US financial crisis. Investors may rationally pay more attention to the announcements that contain information about the relevant risk factors driving interest rates and the risk premia (such as housing market related news during the crisis), which are critical in determining exchange rates. If investors believe that the Fed's concerns about the real-estate market are affecting its policy rate decision, investors may place a higher weight on announcements that contain incremental information

Table 4B

Contemporaneous volatility response (transition indicator: Non-farm payroll employment).

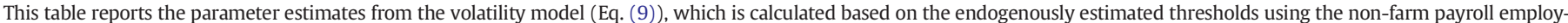

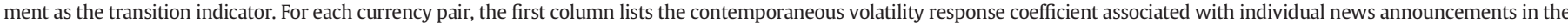

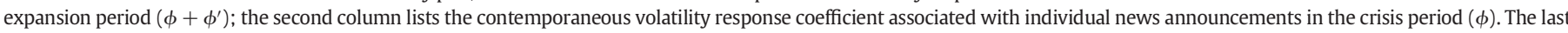
column reports the p-value of the coefficient equality test. *, ${ }^{* *},{ }^{* * *}$ denote statistical significance at $10 \%, 5 \%, 1 \%$ level respectively.

\begin{tabular}{|c|c|c|c|c|c|c|c|c|c|}
\hline \multirow{2}{*}{$\begin{array}{l}\text { NFP } \\
\text { News variables }\end{array}$} & \multicolumn{3}{|l|}{ USD/EUR } & \multicolumn{3}{|l|}{ USD/GBP } & \multicolumn{3}{|l|}{ USD/JPY } \\
\hline & Expans. & Crisis & Pdiff & Expans. & Crisis & Pdiff & Expans. & Crisis & Pdiff \\
\hline Capacity utilization & $0.024^{*}$ & $0.019^{* * *}$ & 0.00 & 0.004 & $0.019^{* * *}$ & 0.41 & 0.001 & $0.040^{* * *}$ & 0.02 \\
\hline GDP advanced report & $0.332^{* * *}$ & -0.004 & 0.00 & $0.088^{* * *}$ & 0.002 & 0.00 & $0.190^{* * *}$ & -0.005 & 0.00 \\
\hline GDP second report & 0.013 & -0.004 & 0.12 & $0.021^{* * *}$ & 0.000 & 0.00 & $0.024^{* * *}$ & $0.019^{* * *}$ & 0.06 \\
\hline GDP third report & -0.002 & 0.004 & 0.07 & -0.006 & 0.005 & 0.20 & 0.000 & -0.008 & 0.67 \\
\hline Industrial production & $-0.035^{* *}$ & -0.006 & 0.00 & -0.008 & $-0.007^{*}$ & 0.45 & 0.008 & $-0.034^{* * *}$ & 0.00 \\
\hline Personal income & $-0.004^{*}$ & $-0.008^{* *}$ & 0.57 & -0.002 & -0.002 & 0.85 & $-0.005^{*}$ & $0.012^{* *}$ & 0.01 \\
\hline Retail sales & $0.035^{* * *}$ & $0.024^{* * *}$ & 0.77 & $0.026^{* * *}$ & $0.017^{* * *}$ & 0.00 & $0.046^{* * *}$ & $0.021^{* * *}$ & 0.00 \\
\hline New home sales & -0.002 & $0.035^{* * *}$ & 0.18 & 0.003 & $0.022^{* * *}$ & 0.05 & $0.013^{* * *}$ & $0.045^{* * *}$ & 0.11 \\
\hline Personal expenditure & 0.007 & -0.002 & 0.65 & $0.005^{* *}$ & 0.001 & 0.11 & $0.010^{* * *}$ & $-0.019^{* * *}$ & 0.00 \\
\hline Business inventories & $-0.007^{*}$ & $-0.005^{*}$ & 0.84 & -0.001 & 0.001 & 0.72 & -0.001 & $0.014^{* * *}$ & 0.07 \\
\hline Construction spending & 0.007 & $0.012^{* * *}$ & 0.01 & $0.008^{* * *}$ & $0.011^{* * *}$ & 0.42 & $0.015^{* * *}$ & $0.013^{* * *}$ & 0.08 \\
\hline Durable orders & $0.032^{* * *}$ & $0.024^{* * *}$ & 0.19 & $0.010^{* * *}$ & $0.022^{* * *}$ & 0.82 & $0.023^{* * *}$ & $0.009^{*}$ & 0.00 \\
\hline Factory orders & 0.003 & $0.011^{* * *}$ & 0.48 & 0.000 & $0.014^{* * *}$ & 0.01 & $0.008^{* *}$ & $0.011^{* * *}$ & 0.52 \\
\hline Consumer price index & $0.037^{* * *}$ & $0.017^{* * *}$ & 0.18 & $0.024^{* * *}$ & 0.002 & 0.00 & $0.037^{* * *}$ & $0.017^{* * *}$ & 0.00 \\
\hline Producer price index & $0.032^{* * *}$ & 0.002 & 0.00 & $0.006^{* * *}$ & 0.000 & 0.03 & $0.013^{* * *}$ & $0.026^{* * *}$ & 0.97 \\
\hline Consumer confidence & $0.024^{* * *}$ & $0.008^{* * *}$ & 0.12 & $0.007^{* * *}$ & $0.009^{* * *}$ & 0.44 & $0.017^{* * *}$ & $0.013^{* * *}$ & 0.02 \\
\hline Housing starts & $0.012^{* * *}$ & 0.002 & 0.01 & $0.007^{* * *}$ & -0.004 & 0.00 & $0.016^{* * *}$ & -0.003 & 0.00 \\
\hline ISM & $0.009^{* * *}$ & $0.017^{* * *}$ & 0.00 & $0.017^{* * *}$ & $0.019^{* * *}$ & 0.02 & $0.030^{* * *}$ & $0.019^{* * *}$ & 0.00 \\
\hline Leading indicators & $0.031^{* * *}$ & $0.010^{* * *}$ & 0.00 & -0.001 & $0.010^{* * *}$ & 0.06 & -0.002 & $0.007^{*}$ & 0.22 \\
\hline Initial claims & $0.013^{* * *}$ & $0.025^{* * *}$ & 0.18 & $0.011^{* * *}$ & $0.007^{* * *}$ & 0.00 & $0.021^{* * *}$ & $0.024^{* * *}$ & 0.00 \\
\hline Nonfarm payrolls & $0.097^{* * *}$ & $0.073^{* * *}$ & 0.00 & $0.068^{* * *}$ & $0.056^{* * *}$ & 0.00 & $0.115^{* * *}$ & $0.075^{* * *}$ & 0.00 \\
\hline Fed funds rate & $0.052^{* * *}$ & $0.077^{* * *}$ & 0.00 & $0.033^{* * *}$ & $0.057^{* * *}$ & 0.28 & $0.041^{* * *}$ & $0.077^{* * *}$ & 0.64 \\
\hline Trade balance & $0.062^{* * *}$ & $0.009^{* * *}$ & 0.33 & $0.037^{* * *}$ & $0.009^{* * *}$ & 0.00 & $0.055^{* * *}$ & 0.003 & 0.00 \\
\hline Treasury budget & -0.003 & $0.033^{* * *}$ & 0.21 & $0.008^{* *}$ & $0.027^{* * *}$ & 0.19 & 0.005 & $0.031^{* * *}$ & 0.08 \\
\hline
\end{tabular}


about the housing sector during the crisis. In fact, Faust et al. (2007) find a similar pattern for the exchange rate reaction to US trade deficit news during the decade preceding 2002. In the earlier part of their sample, when trade deficit was high, investors were quite sensitive to trade deficit news, but this effect waned over time as the deficits eased. More recently, Égert and Kočenda (2014) also find that the responsiveness of CEE exchange rates to verbal central bank communications become important only during the crisis period suggesting the possibility that investors pay more attention central bank policy announcements during times of crisis when the bank's lender of last resort function gain more relevance. Consistent with these findings, Gilbert, Scotti, Strasser, and Vega (2015) document that an announcement's information content (such as its ability to forecast major fundamentals including interest rates) and its timing are critical in determining its impact on asset returns. Overall, the results reported in Faust et al. (2007), Égert and Kočenda (2014) and Gilbert et al. (2015) are consistent with our finding regarding the stronger volatility reaction to new home sales and the Fed funds rate announcements, highlighting the role of economic environment (and the context-specific central bank policy decisions) in generating time-varying news effects.

\section{Robustness}

To test the validity of our main results, we consider various alternative measures of economic activity to analyze the state-dependence in news effects. In their investigation of time-varying announcement effects, Andersen et al. $(2003,2007)$ use the non-farm payroll employment to partition samples into recession and expansion periods. Accordingly, we re-estimate Eq. (9) by incorporating the predicted endogenous transition dates based on the logistic function that uses non-farm payroll employment as the transition indicator (Table 4B). We find that, for the three currency pairs, on average, the magnitude of the volatility response is larger in the expansion period compared to the crisis period for about $40 \%$ of the 24 news categories studied here. The volatility reaction is larger during the crisis for about a fifth of the news items and $40 \%$ of the news items are associated with a statistically equal volatility reaction in either state.

The results also hold when we repeat this exercise by using housing starts as the transition indicator (Table $4 \mathrm{C}$ ). The volatility response pattern based on this alternative macro indicator reveal a more stable reaction to news in foreign exchange markets compared to the volatility response pattern estimated based on the ISM index. In our regression analysis based on the ISM estimates, about a quarter of the news items are associated with statistically indistinguishable market reaction in contractions and expansions. This number goes up to $40 \%$ when estimations are based on housing starts.

Previous studies have found that exchange rate volatility remains elevated up to $2 \mathrm{~h}$ after the announcement of scheduled macroeconomic news (Andersen et al., 2003; Bauwens et al., 2005; Dominquez and Panthaki, 2006). Therefore, as a further robustness check, we estimate the two-hour cumulative volatility response to macroeconomic news (Table 5). Reassuringly, our previous results remain unchanged when we consider the cumulative volatility response to news instead of the contemporaneous volatility reaction to news.

\section{Conclusion}

In this paper, we investigate the volatility reaction to macroeconomic news in the euro, pound and yen markets during the recent global financial crisis. Unlike the traditional event studies that define economic states based on exogenously determined thresholds, we endogenously estimate the probabilities associated with transitioning into a new regime, which allows for the possibility of a gradual as well as an instantaneous regime change. Based on the estimated transition dates, we compute the volatility response coefficients associated with each scheduled news event and analyze whether these responses are sensitive to the changes in the economic environment.

Our analysis documents that although volatility response to most news indicators is larger in expansion periods, the currency markets' reaction to the new home sales and Fed funds rate news was stronger during the crisis period. We also find that the estimated transition function

Table 4C

Contemporaneous volatility response (transition indicator: Housing starts).

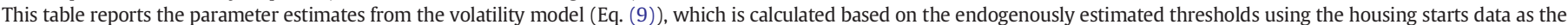

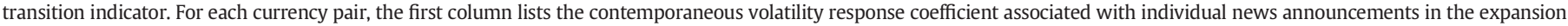

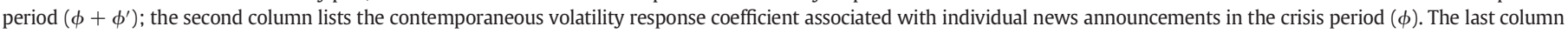
reports the p-value of the coefficient equality test. *, ${ }^{*},{ }^{* * *}$ denote statistical significance at $10 \%, 5 \%, 1 \%$ level respectively.

\begin{tabular}{|c|c|c|c|c|c|c|c|c|c|}
\hline \multirow{2}{*}{$\begin{array}{l}\text { Housing starts } \\
\text { News variables }\end{array}$} & \multicolumn{3}{|l|}{ USD/EUR } & \multicolumn{3}{|l|}{ USD/GBP } & \multicolumn{3}{|l|}{ USD/JPY } \\
\hline & Expans. & Crisis & Pdiff & Expans. & Crisis & Pdiff & Expans. & Crisis & Pdiff \\
\hline Capacity utilization & 0.009 & $0.021^{* * *}$ & 0.80 & -0.003 & $0.019^{* * *}$ & 0.05 & -0.004 & $0.036^{* * *}$ & 0.014 \\
\hline GDP advanced & $0.172^{* * *}$ & $-0.007^{* *}$ & 0.00 & $0.101^{* * *}$ & 0.002 & 0.00 & $0.153^{* * *}$ & 0.001 & 0.000 \\
\hline GDP second & $0.036^{* * *}$ & -0.005 & 0.00 & $0.014^{* *}$ & $0.007^{* *}$ & 0.12 & $0.021^{* *}$ & $0.021^{* * *}$ & 0.235 \\
\hline GDP third & -0.006 & 0.005 & 0.35 & -0.006 & 0.004 & 0.21 & -0.005 & -0.002 & 0.709 \\
\hline Industrial prod. & -0.002 & $-0.009^{*}$ & 0.73 & 0.001 & $-0.009^{* *}$ & 0.38 & 0.006 & $-0.028^{* * *}$ & 0.012 \\
\hline Personal income & 0.001 & -0.006 & 0.29 & -0.002 & 0.000 & 0.52 & -0.005 & $0.009^{* *}$ & 0.012 \\
\hline Retail sales & $0.040^{* * *}$ & $0.025^{* * *}$ & 0.00 & $0.026^{* * *}$ & $0.022^{* * *}$ & 0.00 & $0.038^{* * *}$ & $0.034^{* * *}$ & 0.000 \\
\hline New home sales & -0.001 & $0.035^{* * *}$ & 0.00 & 0.001 & $0.009^{* *}$ & 0.18 & $0.009^{* * *}$ & $0.034^{* * *}$ & 0.051 \\
\hline Personal exp. & $0.022^{* * *}$ & $-0.007^{* *}$ & 0.00 & $0.013^{* * *}$ & -0.003 & 0.00 & $0.017^{* * *}$ & $-0.011^{* * *}$ & 0.000 \\
\hline Business invent. & 0.000 & -0.003 & 0.75 & -0.001 & 0.000 & 0.82 & 0.000 & $0.008^{* * *}$ & 0.306 \\
\hline Construction spend. & $0.020^{* * *}$ & $0.013^{* * *}$ & 0.00 & $0.009^{* * *}$ & $0.013^{* * *}$ & 0.40 & $0.010^{* *}$ & $0.016^{* * *}$ & 0.706 \\
\hline Durable orders & $0.023^{* * *}$ & $0.020^{* * *}$ & 0.00 & $0.014^{* * *}$ & $0.014^{* * *}$ & 0.01 & $0.016^{* * *}$ & $0.022^{* * *}$ & 0.137 \\
\hline Factory orders & $0.008^{* *}$ & $0.007^{* *}$ & 0.26 & 0.003 & $0.009^{* * *}$ & 0.60 & 0.004 & $0.012^{* * *}$ & 0.633 \\
\hline CPI & $0.042^{* * *}$ & $0.014^{* * *}$ & 0.00 & $0.021^{* * *}$ & $0.007^{* * *}$ & 0.00 & $0.031^{* * *}$ & $0.027^{* * *}$ & 0.000 \\
\hline PPI & $0.021^{* * *}$ & -0.003 & 0.00 & $0.014^{* * *}$ & 0.000 & 0.00 & $0.014^{* * *}$ & $0.017^{* * *}$ & 0.183 \\
\hline Cons. confidence & $0.024^{* * *}$ & $0.008^{* * *}$ & 0.00 & $0.016^{* * *}$ & $0.007^{* * *}$ & 0.00 & $0.016^{* * *}$ & $0.015^{* * *}$ & 0.083 \\
\hline Housing starts & $0.014^{* * *}$ & 0.006 & 0.00 & $0.007^{* * *}$ & 0.002 & 0.01 & $0.011^{* * *}$ & $0.017^{* * *}$ & 0.581 \\
\hline ISM & $0.025^{* * * *}$ & $0.022^{* * *}$ & 0.00 & $0.016^{* * *}$ & $0.020^{* * *}$ & 0.04 & $0.021^{* * *}$ & $0.028^{* * *}$ & 0.104 \\
\hline Leading indic. & 0.001 & $0.008^{* * *}$ & 0.41 & 0.001 & $0.007^{* * *}$ & 0.45 & 0.002 & 0.005 & 0.864 \\
\hline Initial claims & $0.021^{* * *}$ & $0.025^{* * *}$ & 0.00 & $0.012^{* * *}$ & $0.009^{* * *}$ & 0.00 & $0.016^{* * *}$ & $0.025^{* * *}$ & 0.053 \\
\hline Nonfarm payroll & $0.100^{* * *}$ & $0.077^{* * *}$ & 0.00 & $0.071^{* * *}$ & $0.062^{* * *}$ & 0.00 & $0.093^{* * *}$ & $0.100^{* * *}$ & 0.000 \\
\hline Fed funds rate & $0.059^{* * *}$ & $0.068^{* * *}$ & 0.00 & $0.042^{* * *}$ & $0.047^{* * *}$ & 0.00 & $0.042^{* * *}$ & $0.070^{* * *}$ & 0.141 \\
\hline Trade balance & $0.072^{* * *}$ & $0.008^{* * *}$ & 0.00 & $0.041^{* * *}$ & $0.009^{* * *}$ & 0.00 & $0.059^{* * *}$ & $0.011^{* * *}$ & 0.000 \\
\hline Treasury budget & 0.009 & $0.032^{* * *}$ & 0.33 & $0.022^{* * *}$ & $0.024^{* * *}$ & 0.10 & $0.027^{* * *}$ & $0.026^{* * *}$ & 0.123 \\
\hline
\end{tabular}


Table 5

Cumulative volatility response (transition indicator: ISM index).

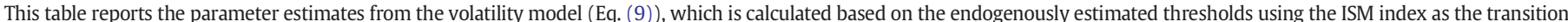

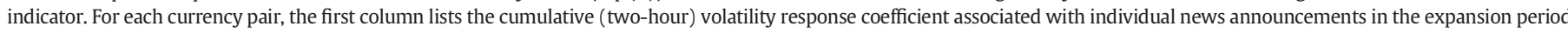

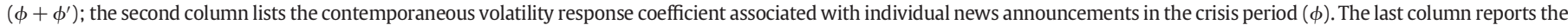
p-value of the coefficient equality test. *, ${ }^{* *},{ }^{* * *}$ denote statistical significance at $10 \%, 5 \%, 1 \%$ level respectively.

\begin{tabular}{|c|c|c|c|c|c|c|c|c|c|}
\hline \multirow{2}{*}{$\begin{array}{l}\text { ISM } \\
\text { News variables }\end{array}$} & \multicolumn{3}{|l|}{ USD/EUR } & \multicolumn{3}{|l|}{ USD/GBP } & \multicolumn{3}{|l|}{ USD/JPY } \\
\hline & Expans. & Crisis & Pdiff & Expans. & Crisis & Pdiff & Expans. & Crisis & Pdiff \\
\hline Capacity utilization & $0.080^{* * *}$ & $0.112^{* * *}$ & 0.48 & $0.044^{*}$ & $0.093^{* * *}$ & 0.93 & $0.075^{* * *}$ & $0.182^{* * *}$ & 0.09 \\
\hline GDP advanced & $0.919^{* * * *}$ & -0.022 & 0.00 & $0.567^{* * *}$ & 0.008 & 0.00 & $1.069^{* * *}$ & -0.031 & 0.00 \\
\hline GDP second & $0.120^{* * * *}$ & -0.027 & 0.00 & $0.098^{* * *}$ & -0.006 & 0.00 & $0.070^{* *}$ & $0.101^{* * *}$ & 0.23 \\
\hline GDP third & $0.066^{* * * *}$ & $-0.142^{* * *}$ & 0.00 & 0.036 & -0.066 & 0.05 & 0.014 & $-0.161^{* * *}$ & 0.83 \\
\hline Industrial prod. & -0.021 & $-0.048^{*}$ & 0.93 & -0.034 & $-0.039^{*}$ & 0.64 & -0.020 & $-0.159^{* * *}$ & 0.07 \\
\hline Personal income & 0.010 & $-0.083^{* * *}$ & 0.01 & -0.007 & 0.001 & 0.66 & -0.015 & $0.075^{* *}$ & 0.08 \\
\hline Retail sales & $0.197^{* * *}$ & $0.143^{* * *}$ & 0.00 & $0.137^{* * *}$ & $0.097^{* * *}$ & 0.00 & $0.215^{* * *}$ & $0.095^{* * *}$ & 0.00 \\
\hline New home sales & 0.014 & $0.176^{* * *}$ & 0.01 & 0.015 & $0.067^{*}$ & 0.45 & $0.060^{* * *}$ & $0.327^{* * *}$ & 0.01 \\
\hline Personal exp. & $0.061^{* * *}$ & 0.027 & 0.05 & $0.042^{* * *}$ & -0.039 & 0.00 & $0.035^{* * *}$ & $-0.105^{* * *}$ & 0.00 \\
\hline Business invent. & 0.020 & $-0.074^{* * *}$ & 0.00 & 0.005 & -0.008 & 0.60 & 0.006 & $0.110^{* * *}$ & 0.00 \\
\hline Construction spend. & $0.115^{* * *}$ & $0.089^{* * *}$ & 0.00 & $0.049^{* * *}$ & $0.090^{* * *}$ & 0.82 & $0.064^{* * *}$ & $0.073^{* * *}$ & 0.75 \\
\hline Durable orders & $0.128^{* * *}$ & $0.083^{* * *}$ & 0.00 & $0.066^{* * *}$ & $0.079^{* * *}$ & 0.14 & $0.110^{* * *}$ & 0.047 & 0.00 \\
\hline Factory orders & $0.036^{* *}$ & $0.030^{*}$ & 0.27 & 0.005 & $0.057^{* * *}$ & 0.17 & $0.040^{* * *}$ & $0.056^{* * *}$ & 0.32 \\
\hline $\mathrm{CPI}$ & $0.188^{* * * *}$ & $0.097^{* * *}$ & 0.00 & $0.118^{* * *}$ & 0.012 & 0.00 & $0.171^{* * * *}$ & $0.072^{* * *}$ & 0.00 \\
\hline PPI & $0.087^{* * *}$ & -0.036 & 0.00 & $0.059^{* * *}$ & $-0.033^{*}$ & 0.00 & $0.036^{* * *}$ & $0.217^{* * *}$ & 0.02 \\
\hline Cons. confidence & $0.114^{* * * *}$ & 0.020 & 0.00 & $0.039^{* *}$ & $0.051^{* * *}$ & 0.47 & $0.080^{* * *}$ & $0.070^{* * * *}$ & 0.01 \\
\hline Housing starts & $0.082^{* * *}$ & -0.043 & 0.00 & $0.041^{* * *}$ & -0.022 & 0.01 & $0.059^{* * *}$ & $0.062^{*}$ & 0.93 \\
\hline ISM & $0.122^{* * *}$ & $0.097^{* * *}$ & 0.00 & $0.087^{* * *}$ & $0.099^{* * *}$ & 0.03 & $0.159^{* * *}$ & $0.074^{* * *}$ & 0.00 \\
\hline Leading indic. & 0.002 & $0.063^{* * *}$ & 0.10 & -0.007 & $0.062^{* * *}$ & 0.02 & -0.005 & $0.033^{*}$ & 0.01 \\
\hline Initial claims & $0.120^{\text {*** }}$ & $0.123^{* * *}$ & 0.00 & $0.057^{* * *}$ & $0.042^{* * *}$ & 0.00 & $0.104^{* * *}$ & $0.116^{* * *}$ & 0.00 \\
\hline Nonfarm payroll & $0.533^{* * *}$ & $0.398^{* * *}$ & 0.00 & $0.365^{* * *}$ & $0.324^{* * *}$ & 0.00 & $0.538^{* * *}$ & $0.392^{\text {*** }}$ & 0.00 \\
\hline Fed funds rate & $0.319^{* * *}$ & $0.342^{* * *}$ & 0.00 & $0.219^{* * *}$ & $0.256^{* * *}$ & 0.00 & $0.245^{* * *}$ & $0.340^{* * *}$ & 0.02 \\
\hline Trade balance & $0.324^{* * * *}$ & 0.025 & 0.00 & $0.188^{* * *}$ & $0.042^{* * *}$ & 0.00 & $0.268^{* * *}$ & -0.019 & 0.00 \\
\hline Treasury budget & $0.030^{*}$ & $0.213^{* * *}$ & 0.00 & 0.009 & $0.185^{* * *}$ & 0.00 & $0.039^{* *}$ & $0.172^{* * *}$ & 0.31 \\
\hline
\end{tabular}

based on the housing starts data exhibits the earliest and most gradual regime change in currency markets. We attribute these findings to the context-specific relevance of the housing and credit sectors in the evolution of the US financial crisis.

The findings may have important implications for investors and institutions who hold and trade foreign assets. By enhancing our understanding of the behavior of exchange rates during a period of elevated uncertainty, this research may help traders and investors improve their assessment of the risks and returns associated with their international assets, which are naturally exposed to exchange rate fluctuations. Our results also suggest that the logistic probability transition functions can be helpful in detecting the early warning signs of an increase in state uncertainty and provide insights for the policymakers regarding the evolution of regime changes in the economy.

\section{References}

Andersen, T. G., \& Bollerslev, T. (1998). Deutsche Mark-Dollar Volatility: Intraday Activity Patterns, Macroeconomic Announcements, and Longer Run Dependencies. The Journal of Finance, 53, 219-265.

Andersen, T. G., Bollerslev, T., Diebold, F. X., \& Vega, C. (2003, March). Micro effects of macro announcements: Real-time price discovery in foreign exchange. American Economic Review, 93(1), 38-62.

Andersen, T. G., Bollerslev, T., Diebold, F. X., \& Vega, C. (2007, November). Real-time price discovery in Stock, bond and foreign exchange markets. Journal of International Economics, 73(2), 251-277.

Balduzzi, P., Elton, E. J., \& Clifton Green, T. (2001). Economic news and bond prices: Evidence from the U.S. Treasury market. Journal of Financial and Quantitative Analysis, $36,523-543$.

Bauwens, L., Ben Omrane, W., \& Giot, P. (2005, November). News announcements, market activity and volatility in the euro/dollar foreign exchange market. Journal of International Money and Finance, 24(7), 1108-1125.

Ben Omrane, W., \& Hafner, C. (2015). Macroeconomic news surprises and volatility spillover in foreign exchange markets. Empirical Economics, Volume 48(Number 2) Fall.

Blanchard, O., \& Simon, J. (2001). The long and large decline in U.S. output volatility. Brookings Papers on Economic Activity, 1, 135-164.

Dominguez, K., \& Panthaki, F. (2006). “What defines 'news' in foreign exchange markets?”. Journal of International Money and Finance, 25, 168-198.

Égert, B., \& Kočenda, E. (2014). The impact of macro news and central bank communication on emerging European forex markets. Economic Systems, 38(1), 73-88.
Ehrmann, M., Osbat, C., Strasky, J., \& Uusküla, L. (2013). The Euro Exchange Rate during the European Sovereign Debt Crisis: Dancing to its own tune. Journal of International Money and Finance, 49, 319-339.

Elsby, M. W. L., Hobijn, B., \& Sahin, A. (2010). The labor market in the Great Recession. Brookings papers on economic activity, Vol. 41(1 (Spring)). (pp. 1-69). Economic Studies Program, The Brookings Institution.

Evans, M. D., \& Lyons, R. K. (2003). How is macro news transmitted to exchange rates? NBER working paper 9433 (January).

Fatum, R., Hutchison, M., \& Wu, T. (2010). "Asymmetries and state dependence: The impact of macro surprises on intraday exchange rates." Working paper, University of Alberta. Journal of the Japanese and International Economics, 26(4), 542-560.

Fatum, Rasmus, \& Yohei Yamamoto (2016). "Intra-safe haven currency behavior during the global financial crisis.". Journal of International Money and Finance, 66, 49-64.

Faust, J., Rogers, J. H., Wang, S., \& Wright, J. H. (2007). The high-frequency response of exchange rates and interest rates to macroeconomic announcements. Journal of Monetary Economics, 54, 1051-1068.

Fratzscher, M. (2009). What explains global exchange rate movements during the financial crisis? Journal of International Money and Finance, 28, 1390-1407.

Gilbert, T., Scotti, C., Strasser, G., \& Vega, C. (2015). Is the intrinsic value of macroeconomic news announcements related to their asset price impact? Finance and economics discussion series 2015-046. Board of Governors of the Federal Reserve System.

Goldberg, L., \& Grisse, C. (2013, October). Time variation in asset price responses to macro announcements: The role of risk. Working paper, NBER (pp. 19523).

Gürkaynak, R., Sack, B., \& Swanson, E. (2005). The sensitivity of long-term interest rates to economic news: Evidence and implication for macroeconomic models. American Economic Review, 95(1), 426-436.

Huang, X. (2015). Macroeconomic news announcements, systemic risk, financial market volatility and jumps.

Laakkonen, H., \& Lanne, M. (2009). Asymmetric news effects on exchange rate volatility: Good vs. bad news in good vs. bad times. Studies in Nonlinear Dynamics $\mathcal{E}$ Econometrics, 14(1), 1-38 (December, De Gruyter).

Mancini, L., Ranaldo, A., \& Wrampelmeyer, J. (2013). Liquidity in the foreign exchange market: Measurement, commonality, and risk premiums. Journal of Finance, 68, 1805-1841.

McQueen, G., \& Roley, V. (1993). Stock prices, news, and business conditions. Review of Financial Studies, 6, 683-707.

Melvin, M., \& Taylor, M. P. (2009). The crisis in the foreign exchange rate market. Journal of International Money and Finance, 28(8), 1317-1330.

Mishra, P., Moriyama, K., \& N'Diaye, P. (2014). Impact of fed tapering announcements on emerging markets.

Neely, C. J. (2011). A survey of announcement effects on foreign exchange volatility and jumps. Federal Reserve Bank of St. Louis Review, 93(5), 361-407.

Neely, C. J., \& Dey, S. R. (2010). A survey of announcement effects on foreign exchange returns. Federal Reserve Bank of St. Louis Review, 92(5), 417-463.

Pearce, D. K., \& Solakoglu, M. N. (2007, October). Macroeconomic news and exchange rates. Journal of International Financial Markets, Institutions \&' Money, 17(4), 307-325. 
Swanson, E. T., \& Williams, J. C. (2013). Measuring the effect of the zero lower bound on medium- and longer-term interest rates. Working paper, Federal Reserve Bank of San Francisco.

Swanson, E. T., \& Williams, J. C. (2014). Measuring the effect of the zero lower bound on yields and exchange rates in the U.K. and Germany. Journal of International Economics, 92, 2-21.

Teräsvirta, T. (1994). Specification, estimation, and evaluation of smooth transition autoregressive models. Journal of the American Statistical Association, 89, 208.218.
Veredas, D. (2006). Macroeconomic surprises and short-term behavior in bond futures. Empirical Economics, 30, 843.866.

Veronesi, P. (1999, Winter). Stock market overreaction to bad news in good times: A rational expectations equilibrium model. Review of Financial Studies, 12(5), 975-1007. 